This PDF is a selection from a published volume from the National Bureau of Economic Research

Volume Title: NBER International Seminar on Macroeconomics 2008

Volume Author/Editor: Jeffrey Frankel and Christopher Pissarides, organizers

Volume Publisher: University of Chicago Press

Volume ISBN: 978-0-226-10732-5

ISSN: 1932-8796

Volume URL: http://www.nber.org/books/fran08-1

Conference Date: June 20-21, 2008

Publication Date: April 2009

Chapter Title: Real Variables, Nonlinearity, and European Real Exchange Rates

Chapter Author: Mark P. Taylor, Hyeyoen Kim

Chapter URL: http://www.nber.org/chapters/c8238

Chapter pages in book: (p. 157 - 193) 


\title{
Real Variables, Nonlinearity, and European Real Exchange Rates
}

\author{
Mark P. Taylor, Barclays Global Investors, University of Warwick, \\ and Centre for Economic Policy Research
}

Hyeyoen Kim, University of Warwick

\section{Introduction}

In this paper we carry out an analysis of European real exchange rate behavior before and after the implementation of Economic and Monetary Union (EMU), that is, the single European currency, in January 1999. In particular, we model real exchange rates for a number of EMU and non-EMU countries against Germany in an explicitly nonlinear framework and allowing for variation in the equilibrium level of the long-run equilibrium real exchange rate using either relative productivities or real diffusion indices.

The relative productivity specification derives from the well-known Harrod-Balassa-Samuelson effect (Harrod 1933; Balassa 1964; Samuelson 1964). According to the Harrod-Balassa-Samuelson effect, countries with rapidly expanding economies should tend to have rapidly appreciating real exchange rates. However, while the Harrod-Balassa-Samuelson effect focuses on a few series in order to explain the equilibrium level of the real exchange rate, the long-run equilibrium real exchange rate may be affected by a wider range of real variables in the macroeconomy. Including the wide range of available real variables in an econometric specification, however, raises a number of practical problems for a modeler, notably the lack of degrees of freedom as well as potential multicollinearity. One way of circumventing this approach is to construct diffusion indices or factors that capture the core variability in a set of macroeconomic time series in a parsimonious fashion (Stock and Watson 1998, 2002a, 2002b; Bernanke and Boivin 2003; Bernanke, Boivin, and Eliasz 2005). In this paper we explore both approaches.

The remainder of the paper is organized as follows. In Section II we examine the underlying rationale for nonlinear real exchange rate adjustment, and in Sections III and IV we briefly discuss the Harrod-Balassa-Samuelson 
and diffusion index methods of capturing variation in the equilibrium real exchange rate, respectively. In Section $\mathrm{V}$ we discuss how these approaches can be incorporated in a nonlinear empirical model, and in Section VI we describe our data set. Our empirical results are reported in Section VII, and in Section VIII we make some concluding remarks.

\section{Nonlinearity and Exchange Rate Dynamics}

The idea of nonlinear adjustment in real exchange rate adjustment has been put forward in a number of papers over the last decade or so. Proponents of this approach argue that exchange rates are relatively insensitive to fundamentals close to equilibrium values but have a tendency to mean-revert strongly as the real exchange rate deviation from equilibrium becomes more pronounced. Transactions costs in international goods arbitrage or institutional rigidities are often cited as a source of nonlinear adjustment of the real exchange rate whereby, for example, relative price adjustment between spatially separated locations may be inactive within a "band of inaction" due to the impossibility of profitable arbitrage of similar goods after allowance for transactions costs (Dumas 1992; Sercu, Uppal, and Van Hulle 1995; O'Connell 1997). The nonlinearity from transaction costs has been examined through the estimation of autoregressive models of the real exchange rate that allow the autoregressive parameter to vary. The threshold autoregressive (TAR) model, for instance, allows for the possibility that there is a band of slow or no convergence around the purchasing power parity level in the real exchange rate, due to transportation costs or other market frictions that create barriers to arbitrage until a threshold equal to the transactions cost is breached. The TAR model, however, is better applied to disaggregated goods prices rather than to the overall real exchange rate, since transactions costs are likely to differ across goods, and so the speed at which price differentials are arbitraged may differ across goods (Obstfeld and Taylor 1997; Cheung, Chinn, and Fujii 2001; Sarno, Taylor, and Chowdhury 2002). Imbs et al. (2005) also suggest that nonlinearity in real exchange rate adjustment may stem from heterogeneous speeds of adjustment in prices at a disaggregated level that may aggregate up into smooth nonlinear adjustment. ${ }^{1}$

An alternative parameterization of nonlinear adjustment, which allows for smooth rather than discrete adjustment of the real exchange rate, is supported on several grounds. In addition to transactions costs, heterogeneity of opinion concerning the equilibrium level of the nominal exchange rate may also generate nonlinearity (Kilian and Taylor 
2003; Taylor 2004; Reitz and Taylor 2009). Kilian and Taylor, for example, argue that the range of beliefs concerning the appropriate direction of the exchange rate moves in order to mean-revert toward equilibrium will tend to narrow as the real exchange rate becomes increasingly deviated from the true but unobserved equilibrium level. Thus close to the equilibrium the real exchange rate is driven by noise traders whereas, as the exchange rate moves away from equilibrium, a greater degree of consensus develops that the exchange rate is misaligned (either overvalued or undervalued), inducing market participants to take stronger positions against the prevailing rate toward the equilibrium. Taylor (2004) also presents empirical evidence for real exchange rate nonlinearity as indirect support of the presence of a "coordination channel" for official intervention, "whereby intervention operations may be seen as fulfilling a coordinating role in that they may organize the 'smart money' to enter the market at the same time" (8; see also Reitz and Taylor 2009). Taylor argues that exchange rate nonlinearity may result from the intervention operations of the central bank: official intervention (either actual or "oral") is more likely to occur and to be effective when the exchange rate has been driven far away from its fundamental equilibrium (see also Fratzscher 2008).

Taylor and Peel (2000), Taylor, Peel, and Sarno (2001), Kilian and Taylor (2003), and Lothian and Taylor (2008) investigate the plausibility of nonlinear exchange rate adjustment using the smooth transition autoregressive (STAR) family of nonlinear models, which allow the degree of mean reversion of a serially correlated process to be a smooth function of the distance from equilibrium. Using the dollar-sterling and dollar-mark nominal exchange rate, Taylor and Peel (2000) find that the exponential smooth transition autoregressive (ESTAR) model parsimoniously describes the deviation from an exchange rate equilibrium determined by monetary fundamentals. Taylor et al. (2001) fit nonlinearly mean-reverting models to real dollar exchange rates over the post-Bretton Woods period. In their study of the half-lives of real exchange rate shocks, they find faster adjustment as the size of shocks increases, whereas for smaller shocks the exchange rate becomes more persistent and, in the neighborhood of equilibrium, unpredictable. The predictability of exchange rates in a nonlinear setting is assessed by Kilian and Taylor (2003), who develop a bootstrap test of the random walk hypothesis in a nonlinear setting and provide evidence of predictability at longer horizons of 2 or 3 years. Lothian and Taylor (2008) examine the Harrod-Balassa-Samuelson effect in a nonlinear framework for the United States, United Kingdom, and France over a period spanning nearly two centuries and find significant evidence of 
nonlinear real exchange rate mean reversion toward an equilibrium that is a function of relative productivity.

In sum, the empirical research reveals that the concept of nonlinearity appears to capture well the salient characteristics of exchange rate dynamics. This nonlinearity may also explain the difficulty researchers have encountered in rejecting the unit root hypothesis for real exchange rates and the observed slow speeds of adjustment in cases in which significant mean reversion has been detected, that is, the "purchasing power parity puzzle" (Rogoff 1996). In particular, if the true data are generated by a nonlinear process, then standard unit root tests have very weak power to reject a false null hypothesis, and the adjustment speed of real exchange rates may be severely underestimated (Taylor et al. 2001; Taylor and Taylor 2004).

\section{The Harrod-Balassa-Samuelson Effect}

According to the well-known Harrod-Balassa-Samuelson effect, the long-run equilibrium real exchange rate should depend on the productivity of the tradable and nontradable sectors in the home and foreign economies. Historically, productivity growth in traded goods sectors has been faster than in nontradable sectors. If the law of one price holds, then the prices of tradables will tend to be equalized across countries, but the prices of nontradables may not. Faster productivity growth raises wages in the tradables sector, and with labor mobile within the economy, wages in the entire economy will rise, leading to a rise in the price of nontradables (since the wage rise is not offset by productivity growth in that sector) and an increase in the overall price index (a function of both tradables and nontradables prices), resulting in an appreciation of the real exchange rate, other things equal.

The standard Harrod-Balassa-Samuelson effect may be illustrated in a simple two-country, two-goods context (Froot and Rogoff 1991) as follows. A standard Cobb-Douglas technology is assumed:

$$
Y_{I}=A_{I} K_{I}^{\phi_{I}}, \quad I=T, N,
$$

where $T_{I}, K_{I}$, and $A_{I}$ denote, respectively, the output-labor ratio, the capitallabor ratio, and productivity in sector $T$ (tradables) or $N$ (nontradables), respectively. Suppose that factors are perfectly mobile across the tradable and nontradable sectors and the two sectors are characterized by perfect competition, so that there is long-run real rate of return equalization in 
capital across economies and long-run real wages are equalized in the long run across sectors within economies:

$$
\begin{gathered}
R=\phi_{T} A_{T} K_{T}^{\phi-1}, \quad R=\frac{P_{N}}{P_{T}} \phi_{N} A_{N} K_{N}^{\phi-1}, \\
W=\left(1-\phi_{T}\right) A_{T} K_{T}^{\phi_{T}}, \quad W=\frac{P_{N}}{P_{T}}\left(1-\phi_{N}\right) A_{N} K_{N}^{\phi_{N}},
\end{gathered}
$$

where $R$ denotes the real long-run return to capital, $W$ is the long-run real wage rate (measured in tradables), and $P_{N T} / P_{T}$ is the relative price of nontradables to tradables. Taking logarithms and totally differentiating (2) and (3), we derive

$$
d \ln K_{N}=d \ln K_{T}=d \ln W=d \ln A_{T}\left(1-\phi_{T}\right)^{-1}
$$

and

$$
d \ln \left(\frac{P_{N}}{P_{T}}\right)=\left(1-\phi_{N}\right)\left(1-\phi_{T}\right)^{-1} d \ln A_{T}-d \ln A_{N} .
$$

Equation (5) incorporates the Harrod-Balassa-Samuelson condition that relatively higher productivity growth in the tradables sector will tend to generate a rise in the relative price of nontradables. Integrating (5), we can obtain the following logarithmic form of the relative price of nontradables (indicating logarithms by the use of lowercase letters): ${ }^{2}$

$$
p_{N}-p_{T}=\left(1-\phi_{N}\right)\left(1-\phi_{T}\right)^{-1} a_{T}-a_{N} \text {. }
$$

The overall price level, $p$, is a geometric average of its tradable and nontradable price components:

$$
p=p_{T}+(1-\lambda)\left(p_{N}-p_{T}\right) .
$$

Assuming that the law of one price holds among tradable goods,

$$
p_{T}^{*}=s+p_{T},
$$

where $s$ is the logarithm of the nominal exchange rate (foreign price of home currency). Provided that equations similar to (6) and (7) hold in the foreign economy, the following expression for the long-run real exchange rate is obtained:

$s-p^{*}+p=(1-\lambda)\left[\left(\frac{1-\phi_{N}}{1-\phi_{T}}\right) a_{T}-a_{N}\right]-(1-\lambda)\left[\left(\frac{1-\phi_{N}^{*}}{1-\phi_{T}^{*}}\right) a_{T}^{*}-a_{N}^{*}\right]$. 
For simplicity, if we assume that productivity in the nontradables sector in each country is close to zero, equation (9) simplifies to

$$
s-p^{*}+p=(1-\lambda)\left[\left(\frac{1-\phi_{N}}{1-\phi_{T}}\right) a_{T}\right]-(1-\lambda)\left[\left(\frac{1-\phi_{N}^{*}}{1-\phi_{T}^{*}}\right) a_{T}^{*}\right] .
$$

Equation (10) illustrates the Harrod-Balassa-Samuelson effect: relatively high levels of productivity in tradables will generate a real exchange rate appreciation. Equivalently, rich countries will tend to have a higher exchange rate-adjusted price level on average. While this analysis is in some sense timeless and frictionless and does not model the dynamics of adjustment, we can think of it as applying to the long-run determination of the equilibrium real exchange rate.

The empirical evidence provides mixed results on the Harrod-BalassaSamuelson effect, as surveyed by Froot and Rogoff (1995) and Taylor and Taylor (2004). There are several explanations for such mixed results. Bergin, Glick, and Taylor (2006), for example, propose models with endogenous tradability of products and suggest that this effect has been variable over time. Devereux (1999) also argues that the positive link between relative productivity and real exchange rates can be reversed in some cases with the presence of endogenous productivity gain in distribution services. ${ }^{3}$ In this framework, the formal presentation of the reversed Harrod-Balassa-Samuelson effect may be introduced with the price of tradables as a subprice index given by the wholesale price of tradables, $P_{W}$, and the price of distribution services, $P_{D}$ :

$$
P_{T}=P_{W}^{\beta} P_{D}^{1-\beta} \text {. }
$$

In addition, assume that the distribution sector comprises a continuum of monopolistically competitive firms of total measure $\theta$ and the technology for the production of the distribution sector is

$$
X(i)+\delta=A_{x} K_{x}^{\phi_{T}}
$$

where $X(i)$ is output of distribution services of firm $i$ and $\delta$ is a fixed cost. The consumption of distributional sector services is given by

$$
D_{T}=\left[\int_{0}^{\theta} X(j)^{\rho} d j\right]^{1 / \rho}
$$

where $0 \leq \rho \leq 1$. Equation (13) implies that there are increasing returns to specialization in the distribution sector. The term $\theta$ represents an endogenous productivity effect in distributional services, and $\rho$ is the elasticity of 
substitution between distributional services (the lower $\rho$ is, the greater the strength of this specialization effect).

The individual firms that produce specialized distribution services are monopolists and set price at a markup over marginal cost. In a symmetric equilibrium, this gives

$$
P_{x}=\frac{1}{\rho} \frac{W}{A_{x}}, \quad P_{w}=\frac{W}{A_{T}} .
$$

The efficient pricing of the distribution composite implies

$$
P_{D}=\theta^{1-(1 / \rho)} P_{x}
$$

Now suppose that productivity in the distribution sector grows at the same rate as for tradables, $a_{T}=a_{W}$, and endogenous productivity, $\theta$, grows as

$$
d \ln \theta=\left(\frac{1}{1-\phi_{T}}\right) d a_{T} .
$$

Then, when we take logarithms of equations (11), (14), and (15), the domestic price level is determined by ${ }^{4}$

$$
p=\left[\left(\frac{1}{1-\phi_{T}}\right)\left(1-\frac{1}{\rho}\right)(1-\beta) \lambda+\left(\frac{1-\phi_{N}}{1-\phi_{T}}\right)(1-\lambda)\right] a_{T}-(1-\lambda) a_{N} .
$$

From equation (17), when productivity levels in the foreign country are kept constant, the real exchange rate may tend to appreciate or depreciate. If $\beta=1$, the Harrod-Balassa-Samuelson effect applies since the growth of productivity of $a_{T}$ increases the price level. But when $\beta<1$, the first term in equation (17) is negative, decreasing the domestic price level, and the real exchange rate possibly depreciates as a result of the endogenous productivity "deepening" in the distribution sector. ${ }^{5}$

\section{Diffusion Indices}

The basic idea of factor analysis is to summarize the information in a large number of economic time series in such a way as to capture most of the variability. Suppose that $X_{t}$ denotes an $N$-dimensional vector of $I(1)$ time-series variables. If $X_{t}$ is described by a factor model, it can be written as the sum of two orthogonal components: the "common component," which is driven by a small number of "factors," and the "idiosyncratic component," which is specific to a particular variable:

$$
X_{t}=\Lambda_{t} F_{t}+\xi_{t}
$$


and

$$
F_{t}=\delta F_{t-1}+e_{t}
$$

where $X=\left(X_{1}, \ldots, X_{N}\right)$ and $X_{i}=\left(x_{i 1}, \ldots, x_{i T}\right)^{\prime}$ for $i=1, \ldots, N ; F_{t}$ is the $(r \times 1)$ vector of common factors; $\Lambda_{t}$ is a factor loadings matrix; and $\xi_{t}$ is the $(n \times 1)$ idiosyncratic disturbance, which can be correlated and serially correlated. In equation (18), the $F_{t}$ is unobservable and only $X_{t}$ is observable. It is also noted that $x_{i t}$ and $x_{j t}$ are correlated because they share a common $F_{t}$.

There are at least two ways that have been proposed to estimate the unobservable factors, namely, maximum likelihood and a two-step estimation procedure involving principal components. In this study, we use the principal components method as proposed by Stock and Watson (1998, 2002a, 2002b) and Bai (2003), whereby factors are estimated by the method of principal components in the first step followed by the estimation of time-series models of the factors in the second step. ${ }^{6}$

In practice, the factors may be estimated by solving the following eigenvalue problem for the sample covariance matrix:

$$
\Xi_{0} Y_{r}=Y_{r} D_{r},
$$

where $\Xi_{0}$, estimated as $X X^{\prime} /\left(T^{2} N\right)$, is the covariance matrix of the standardized data matrix for a sample size $T ; X=\left[X_{1} X_{2} \cdots X_{T}\right]^{\prime}$; and $Y_{r}=\left[y_{1} \cdots y_{r}\right]$ is the $(N \times r)$ matrix whose columns are the $r$ eigenvectors that correspond with the first $r$ largest eigenvalues of the covariance matrix, $\Xi_{0}$. The matrix $D_{r}$ then denotes a diagonal matrix representing the first $r$ largest eigenvalues. From the solution to this problem, the first $r$ principal components are defined as

$$
\hat{F}_{t}=Y_{r}^{\prime} \hat{X}_{t}
$$

Since the principal components are by construction orthogonal to one another, there is no redundant information in individual factors.

In practice, $N$, the number of time series making up $X_{t}$, may be very large. If most of the variation in $X_{t}$ is contained in the first $r$ common factors, however, then the dimensionality of the data problem may be reduced from $N$ to $r$, and $r$ will typically be a small number. Insofar as the resulting factors or diffusion indices can be used to augment an econometric model, the applied modeler may then be able to reflect the complexities of the economy in a parsimonious fashion with a workable number of degrees of freedom (see, e.g., Bernanke et al. 2005). 


\section{Empirical Specification of Nonlinear Real Exchange Rate Adjustment}

Smooth transition autoregressive (STAR) models were first generalized into the econometrics literature by Granger and Teräsvirta (1993). In a STAR model the speed of adjustment toward equilibrium takes place in every period, but the speed varies smoothly with the extent of the deviation from equilibrium. As discussed briefly above, there are sound theoretical reasons for expecting that nonlinear real exchange rate adjustment and STAR models have indeed been successfully applied to real and nominal exchange rates (e.g., Michael, Nobay, and Peel 1997; Taylor and Peel 2000; Taylor et al. 2001; Kilian and Taylor 2003). ${ }^{7}$ In line with this previous exchange rate research, our paper focuses on the exponential smooth transition autroregressive or ESTAR specification, which implies symmetric adjustment above and below equilibrium and which has been found to be particularly applicable to exchange rates. The first-order ESTAR specification for a time-series process $q_{t}$ may be written as ${ }^{8}$

$$
q_{t}-\mu=\alpha\left(q_{t-1}-\mu\right)+\beta\left(q_{t-1}-\mu\right) \Phi\left[\gamma ; q_{t-1}-\mu\right]+e_{t} .
$$

In the present application, $q_{t}$ is the real exchange rate defined as

$$
q_{t} \equiv s_{t}+p_{t}-p_{t}^{*}
$$

and $\Phi\left[\gamma ; q_{t-1}-\mu\right]$ is the exponential transition function specified as

$$
\Phi\left[\gamma ; q_{t-1}-\mu\right]=1-\exp \left[-\gamma\left(q_{t-1}-\mu\right)^{2}\right] .
$$

The exponential transition function determines the degree of mean reversion and is itself governed by the nonlinear adjustment parameter, $\gamma$, which effectively determines the speed of mean reversion, and the parameter $\mu$, which is the equilibrium level of the real exchange rate. The domain of $\Phi\left[\gamma ; q_{t-1}-\mu\right]$ is the real line, its range is bounded by zero and unity, and it is symmetrically inverse bell-shaped around zero.

The transition parameter $\gamma>0$ determines the speed of transition between two extreme regimes. When the real exchange rate is very close to the equilibrium level $\mu$, for instance, the nonlinear part of equation (22) disappears as $\Phi(0) \approx 0$, and the real exchange rate is close to an $\operatorname{AR}(1)$ process:

$$
q_{t}=(1-\alpha) \mu+\alpha q_{t-1}+e_{t} .
$$

As departures from the equilibrium increase, however, the argument of the transition function gets larger and larger, and in the limit, the transition 
function approaches unity: $\lim _{|x| \rightarrow \infty} \Phi[\gamma ; x]=1$. In the limit, therefore, (22) becomes another AR(1) model:

$$
q_{t}=(1-\alpha-\beta) \mu+(\alpha+\beta) q_{t-1}+e_{t} .
$$

For intermediate deviations of the real exchange rate from equilibrium, the process will display an intermediate speed of adjustment.

Note that, in particular, with $\alpha=1,(25)$ implies that the real exchange rate will follow a random walk in the neighborhood of equilibrium, whereas if, in addition, $\beta<0$, the real exchange rate will become increasingly mean-reverting as the deviation from equilibrium increases.

The preceding analysis implicitly assumes that the real exchange rate has a constant equilibrium, $\mu$, but we can relax this assumption by allowing for a time-varying long-run equilibrium. In this paper, two types of long-run equilibrium are examined: one determined by the HarrodBalassa-Samuelson effect by including productivity differentials in the specification and the other augmented by diffusion indices.

First, we allow the Harrod-Balassa-Samuelson effect as a determinant of long-run equilibrium in the real exchange rate by modeling time variation in the equilibrium level as a function of relative productivity:

$$
\mu_{t}=\mu_{0}+\mu_{1}\left(a_{t}-a_{t}^{*}\right),
$$

where $a_{t}$ and $a_{t}^{*}$ represent the productivity of the home and foreign economy, respectively.

If diffusion indices are incorporated into the long-run equilibrium level of $q_{t}, \mu_{t}$ may be represented as

$$
\mu_{t}=c+b F_{t} .
$$

When the factors in a nonlinear function are combined, the equilibrium real exchange rate becomes time varying and dependent on macroeconomic fundamentals estimated by the common factors or diffusion indices. We term ESTAR models of this kind, in which diffusion indices or macroeconomic factors have been added into the specification, "factoraugmented ESTAR" or FESTAR models.

\section{Data}

Our data sets consist of two parts: real exchange rates and macroeconomic real variables. Given the European focus of this study, we concentrated on a set of intra-European real exchange rates against Germany. In particular, we considered German real exchange rates against six major European 
economies: the United Kingdom, Switzerland, Denmark, France, Austria, and Italy. Among these, the United Kingdom, Switzerland, and Denmark have not participated in EMU, whereas, in common with Germany, France, Austria, and Italy have adopted the single European currency, the euro, as their official currency since January 1999. For the EMU countries, we therefore use a floating nominal exchange rate against the German mark before 1999 and a fixed nominal rate afterward. Domestic and foreign price levels were approximated by monthly observations on consumer price indices (CPI). Then the real exchange rate was constructed with these data in logarithmic form as in equation (23), with $s_{t}$ taken as the logarithm of the nominal exchange rate against the German mark, $p_{t}$ as the logarithm of the consumer price level of the home country, and $p_{t}^{*}$ as the logarithm of the consumer price level of the foreign country (Germany). Nominal exchange rates after January 1999 were constructed on the basis of the euro rate adjusted by the fixed conversion rate at the time of conversion to EMU, although this in fact affects only the mean of the real exchange rate. The real exchange rates of EMU countries against Germany after January 1999 are effectively scaled CPI ratios.

The other part of the data set comprises macroeconomic time series for all economies, taken from DataStream. The composition of the monthly data sets was determined by the data availability, which represents real variables such as real production, employment, consumption, orders, earnings, and retail sales. Each time series was transformed to be seasonally adjusted, and logarithmic transformations were taken for nonnegative series that are not already represented in percentages. The total number of time series collected was 19, 22, 14, 16, 21, 17, and 15 for Germany, the United Kingdom, Switzerland, Denmark, France, Austria, and Italy, respectively. ${ }^{9}$ In addition, the productivity of one country is measured by real industrial production data divided by industrial employment. $^{10}$

With post-German reunification taken as the starting point for our empirical analysis, our sample period runs from January 1991 to June 2007. The data sample period is further split into a period of pre- and postimplementation of EMU in January 1999 in order to see the impact of introduction of the euro on real exchange rate adjustment. For the preimplementation period, the data therefore range from January 1991 to December 1998 (96 observations), and the EMU period covers from January 1999 to June 2007 (102 observations). The real exchange rates are normalized to zero at the beginning of each observation period; 
the same normalization is applied to the productivity of each country in each period. For construction of the diffusion indices, in each of the two subperiods the real variables are standardized to zero mean and unit variance over the sample in order to estimate the scale-invariant principal components.

\section{Empirical Results}

A. Movement of Productivity, Competitiveness, and Real Exchange Rates since January 1991

As a preliminary examination of the Harrod-Balassa-Samuelson effect on European real exchange rates, it is useful to examine the trends of a few macroeconomic time series that reflect productivity and competitiveness to see in general terms how these are related to fluctuations in the real exchange rate. ${ }^{11}$

Figure 1 illustrates movements in productivity and relative productivity against Germany for each of the six non-German countries. While productivity has clearly risen in each country over the sample period, relative productivity against Germany improves over the period only for the United Kingdom, Denmark, and Austria. In figure 2, we have plotted relative productivity and relative unit labor costs for each country against Germany, with relative unit labor costs defined as the ratio of relative productivity and wages. ${ }^{12}$ The growth of relative unit labor costs is notably higher than the growth of relative productivity in Switzerland, France, and Italy, whereas there is perhaps some evidence of general comovement between these series in the United Kingdom and Denmark.

In figure 3 we have plotted the real exchange rate against Germany and relative productivity for each country. With the possible exception of Italy, there does indeed appear to be some comovement between the real exchange rate and relative productivity evident, at least in an informal sense, from figure 3, suggesting a possible link between the two, consistent with a Harrod-Balassa-Samuelson effect.

\section{B. Harrod-Balassa-Samuelson Effect}

In this subsection, we report estimation results of our real exchange rate models with an allowance for a time-varying long-run equilibrium based on the Harrod-Balassa-Samuelson effect. We tested the restrictions on the autoregressive parameters $\alpha=1, \beta=-1$, and in no case 
UK

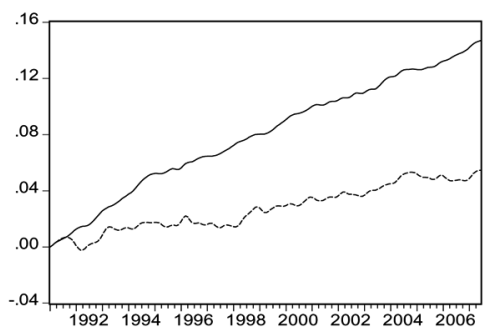

Denmark

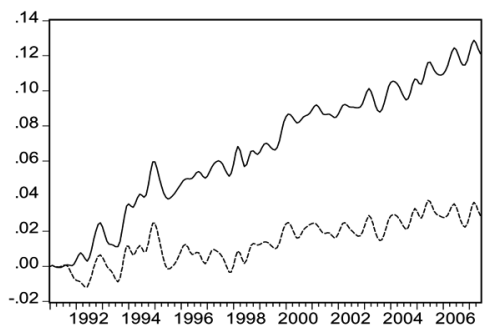

Austria

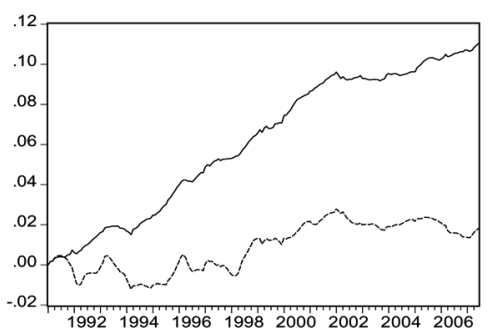

Switzerland

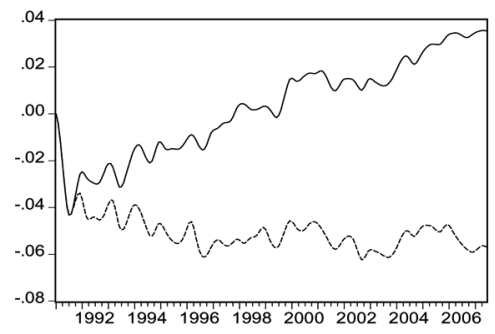

France

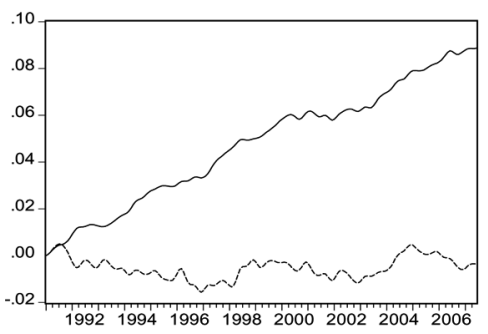

Italy

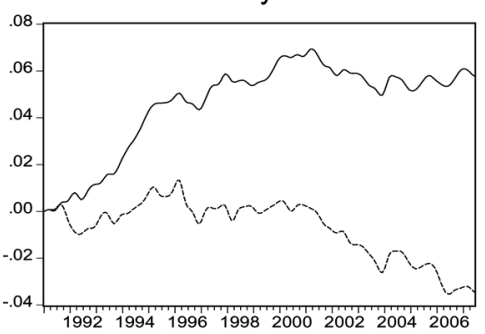

Productivity

Relative Productivity

Fig. 1. Productivity and relative productivity. Both productivity and relative productivity are normalized as zero at the initial period.

could we reject them at the $5 \%$ significance level. These restrictions imply an equilibrium of the real exchange rate, in the neighborhood of which $q_{t}$ is close to a random walk, becoming increasingly mean-reverting with the absolute size of the deviation from equilibrium. Thus, the estimated ESTAR model had the form

$$
q_{t}=q_{t-1}-\left(q_{t-1}-\mu\right) \Phi\left[\gamma ; q_{t-1}-\mu\right]+e_{t} .
$$


UK

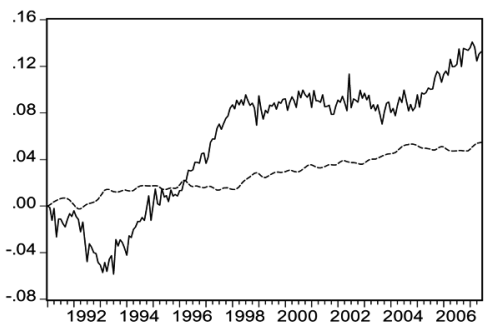

Denmark

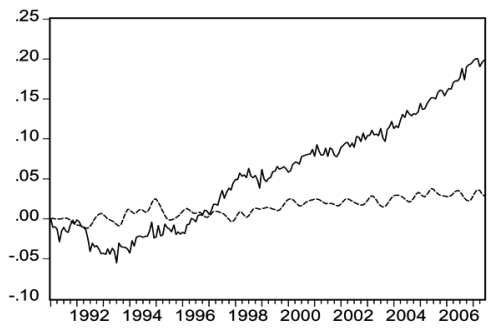

Austria

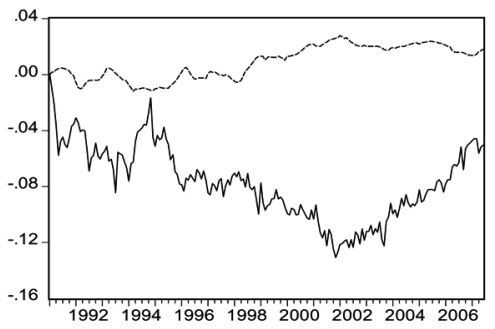

\section{Switzerland}

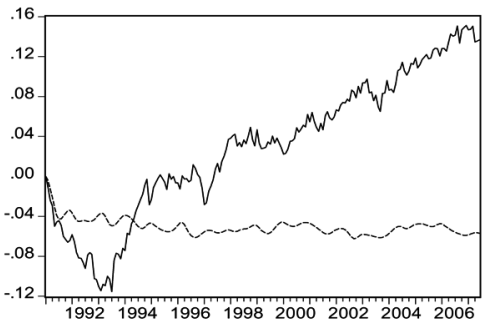

France

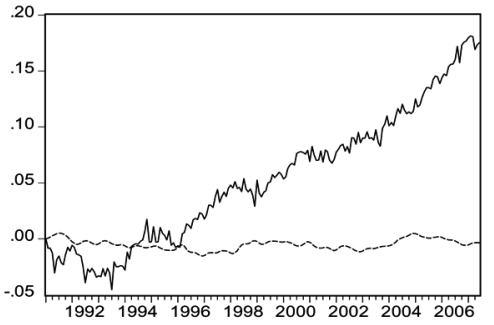

Italy

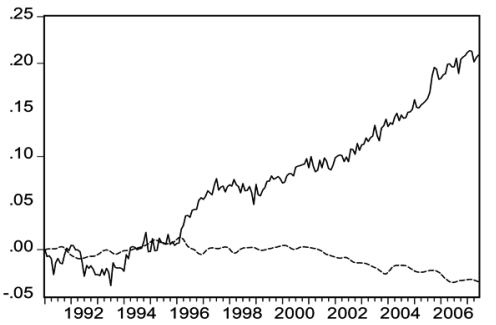

\section{Relative Unit Labor Costs
Relative Productivity}

Fig. 2. Relative unit labor costs and relative productivity. Both relative productivity and relative unit labor costs are normalized as zero and unit variance.

When relative productivity, measured by the aggregate term (real income per employee), is included in the model, the model is specified as

$$
\begin{aligned}
q_{t}= & q_{t-1}-\left[q_{t-1}-\mu_{0}-\mu_{1}\left(a_{t-1}-a_{t-1}^{*}\right)\right] \\
& \times\left(1-\exp \left\{-\gamma\left[q_{t-1}-\mu_{0}-\mu_{1}\left(a_{t-1}-a_{t-1}^{*}\right)\right]^{2} / \sigma_{q}^{2}\right\}\right)+e_{t},
\end{aligned}
$$

where $a_{t}^{*}$ indicates German productivity and $a_{t}$ is the productivity of the corresponding country. The exponential term is scaled by the sample variance of the real exchange rate, $\sigma_{q}^{2}$, in order to facilitate the choice 

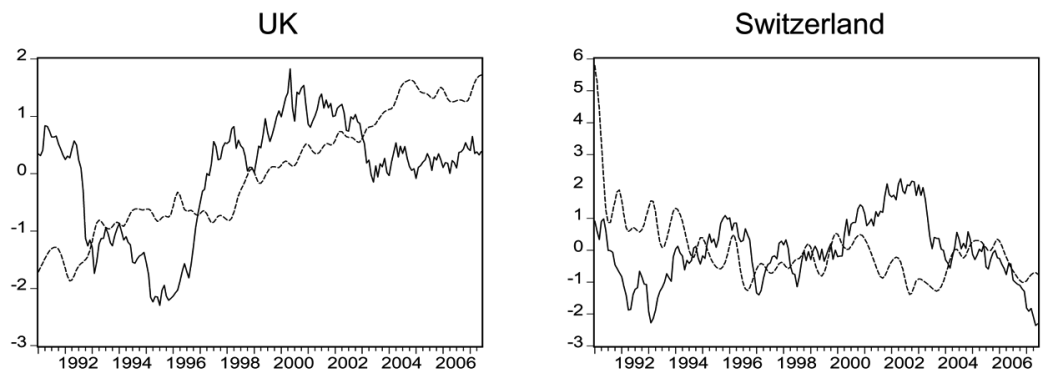

Denmark

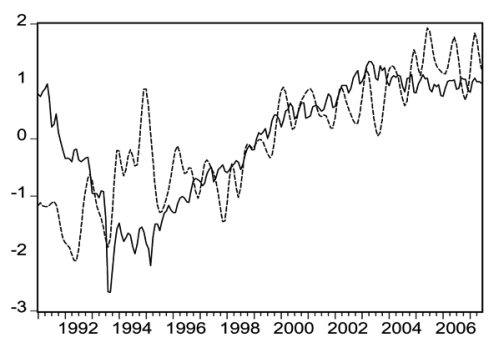

France

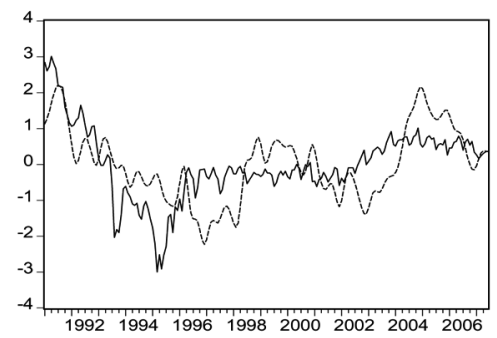

Austria

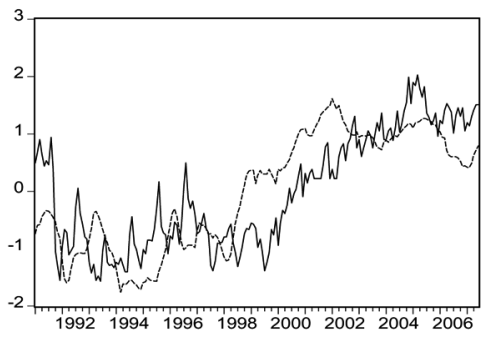

Italy

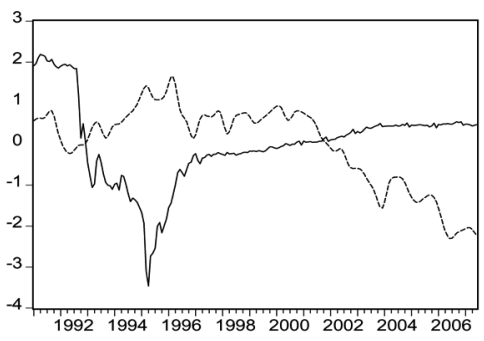

Real Exchange Rate

Relative Productivity

Fig. 3. Real exchange rates and relative productivity. Real exchange rates and relative productivity are standardized as zero mean and unit variance.

of starting values in the nonlinear estimation (Teräsvirta 1994). In order to pick up the Harrod-Balassa-Samuelson effect, the sign of $\mu_{1}$ should be positive.

On the basis of equation (30), the most parsimonious form was estimated with a general-to-specific procedure in which insignificant parameters were excluded discretely. Our final parsimonious estimated form of equation (30) for each country is reported in table 1 . In each entry in the table, the estimated values of coefficients are reported with $t$-statistics; 


\section{Table 1}

Estimated Nonlinear Models: Harrod-Balassa-Samuelson Effect

\begin{tabular}{|c|c|c|}
\hline & 1991-98 & 1999-2007 \\
\hline \multicolumn{3}{|c|}{ United Kingdom: } \\
\hline \multirow[t]{3}{*}{$\gamma$} & .016 & .1288 \\
\hline & (1.305) & (3.796) \\
\hline & {$[0.45]$} & {$[.000]$} \\
\hline \multirow[t]{2}{*}{$\mu_{0}$} & -.050 & .043 \\
\hline & $(3.171)$ & $(11.300)$ \\
\hline \multirow[t]{3}{*}{$\mu_{1}$} & $\cdots$ & -1.242 \\
\hline & & $(2.875)$ \\
\hline & $z 1=[.183] ; z 2=[.006]$ & $z 1=[.161] ; z 2=[.243]$ \\
\hline \multicolumn{3}{|c|}{ Switzerland: } \\
\hline \multirow[t]{3}{*}{$\gamma$} & .033 & .007 \\
\hline & $(2.020)$ & $(1.331)$ \\
\hline & {$[.186]$} & {$[.47]$} \\
\hline \multirow[t]{2}{*}{$\mu_{0}$} & -.027 & $\ldots$ \\
\hline & (3.126) & \\
\hline \multirow[t]{3}{*}{$\mu_{1}$} & -.1177 & $\ldots$ \\
\hline & $(.580)$ & 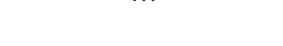 \\
\hline & $z 1=[.583] ; z 2=[.000]$ & $z 1=[.237] ; z 2=[.825]$ \\
\hline \multicolumn{3}{|c|}{ Denmark: } \\
\hline \multirow[t]{3}{*}{$\gamma$} & .022 & .060 \\
\hline & $(2.424)$ & $(2.735)$ \\
\hline & {$[.072]$} & {$[.036]$} \\
\hline \multirow[t]{2}{*}{$\mu_{0}$} & -.025 & .013 \\
\hline & (7.011) & $(8.250)$ \\
\hline \multirow[t]{3}{*}{$\mu_{1}$} & .019 & .377 \\
\hline & $(.052)$ & $(2.010)$ \\
\hline & $z 1=[.322] ; z 2=[.000]$ & $z 1=[.581] ; z 2=[.203]$ \\
\hline \multicolumn{3}{|c|}{ France: } \\
\hline \multirow[t]{3}{*}{$\gamma$} & -.022 & .083 \\
\hline & $(6.872)$ & $(2.715)$ \\
\hline & {$[.095]$} & {$[.028]$} \\
\hline \multirow[t]{2}{*}{$\mu_{0}$} & .018 & .004 \\
\hline & $(2.119)$ & (8.035) \\
\hline \multirow[t]{2}{*}{$\mu_{1}$} & $\ldots$ & $\ldots$ \\
\hline & $z 1=[.213] ; z 2=[.064]$ & $z 2=[.805] ; z 3=[.614]$ \\
\hline \multicolumn{3}{|c|}{ Austria: } \\
\hline \multirow[t]{3}{*}{$\gamma$} & .057 & .063 \\
\hline & $(2.258)$ & $(2.488)$ \\
\hline & {$[.100]$} & {$[.110]$} \\
\hline \multirow[t]{2}{*}{$\mu_{0}$} & -.006 & .004 \\
\hline & $(1.678)$ & $(4.041)$ \\
\hline \multirow[t]{3}{*}{$\mu_{1}$} & .330 & .486 \\
\hline & $(2.012)$ & $(3.477)$ \\
\hline & $z 2=[.100] ; z 3=[.004]$ & $z 2=[.245] ; z 3=[.013]$ \\
\hline
\end{tabular}


Table 1

Continued

\begin{tabular}{ccc}
\hline & $1991-98$ & $1999-2007$ \\
\hline Italy: & & \\
$\gamma$ & .013 & .017 \\
& $(1.756)$ & $(1.606)$ \\
& {$[.322]$} & {$[.538]$} \\
$\mu_{0}$ & -.074 & .015 \\
& $(4.426)$ & $(5.671)$ \\
$\mu_{1}$ & $\ldots$ & $\ldots$ \\
& $z 2=[.000] ; z 3=[.222]$ & $z 2=[.000] ; z 3=[.356]$
\end{tabular}

Note: Figures in parentheses are $t$-statistics. $z 1$ is the White (1980) heteroskedasticity test statistic for serial correlation; $z 2$ is the Lagrange multiplier test for serial correlation; $z 3$ is the Lagrange multiplier test statistic for remaining nonlinearity; figures in brackets are marginal significance levels. The marginal significance levels for the estimated transition parameters were calculated by Monte Carlo simulation under the null hypothesis of a unit root $\mathrm{AR}(1)$ process.

blank cells imply that the estimated coefficient was insignificant at the $5 \%$ level and was set to zero. ${ }^{13}$

From table 1, nonlinear estimation with allowance for the HarrodBalassa-Samuelson effect can be summarized by the following key features. In both periods, $t$-statistics for the estimated value of $\gamma$ suggest that it is significantly different from zero. However, the ratio of this estimated coefficient to its standard error cannot be referred to the Student $t$ or normal distribution for purposes of inference because under the null hypothesis $H_{0}: \gamma=0$ the process becomes a linear unit root process. ${ }^{14}$ In fact, a test of $H_{0}: \gamma=0$ is effectively a test for a linear unit root in the real exchange rate against the alternative hypothesis of nonlinear mean reversion toward a (constant or time-varying) long-run equilibrium. ${ }^{15}$ Since the distribution of $\gamma$ is unknown under the null hypothesis, we calculated the empirical significance levels using Monte Carlo simulation under the null hypothesis of a unit root AR(1) process, that is, $\gamma=0$, in order to generate the empirical significance level. ${ }^{16}$ This is reported in brackets in table 1 . The estimated transition parameter is significantly different from zero in most cases except in the first period for the United Kingdom and in both periods for Switzerland and Italy. ${ }^{17}$ In the EMU period especially, strong evidence of nonlinear mean reversion is accompanied by expected faster adjustment speeds in terms of higher estimated values of $\gamma$ for the United Kingdom, Denmark, France, and Austria.

When we look at the Harrod-Balassa-Samuelson effect, the estimated coefficient for the relative productivity term, $\mu_{1}$, is strongly significantly 
different from zero for the United Kingdom (second period), Denmark (second period), and Austria (both periods). For the United Kingdom (first period), Switzerland (both periods), Denmark (first period), France (both periods), and Italy (both periods), however, there is no significant evidence of such an effect. Among them, the coefficient in relative productivity is correctly signed for Denmark, France, and Austria: relative higher productivity generates a real appreciation of the equilibrium value. This result is also consistent with the preliminary finding in figure 3. But the sign is reversed relative to the Harrod-Balassa-Samuelson prior for the United Kingdom, which may possibly be attributed to the growth of the service sector in Germany after reunification.

\section{Diffusion Indices as Determinants of Long-Run Equilibrium}

As specified in Section II, real factors for each country were estimated using two-step principal components for each period (before and after implementation of EMU). From the estimated factors based on real variables, we calculated the percentage of total variability of the data sets explained by each factor and found that the first principal component explained the major portion of total variability. The actual contribution of the first principal component to total variability is reported for each country in table 2 . For all economies, the first principal component accounts for around a half to three-quarters of variability of the data set, ranging from $45 \%$ to $77 \%$. Given this result, we fixed the number of factors included in the model in both periods at one.

The relationship between the estimated factor and real variables was further examined by means of a simple ordinary least squares regression in order to shed light on which real variables are most important for the estimated factor. In particular, each of the series is first-differenced and regressed against the first-differenced empirical factor, and the resulting $R^{2}$ coefficients are graphed in figure 4 . As figure 4 shows, real output is

Table 2

Percentage of Total Variability Explained by First Principal Component

\begin{tabular}{|c|c|c|}
\hline & January 1991-December 1999 & January 2000-June 2007 \\
\hline Germany & 51.6 & 51.0 \\
\hline United Kingdom & 65.5 & 58.8 \\
\hline Switzerland & 45.2 & 53.8 \\
\hline Denmark & 77.1 & 53.4 \\
\hline France & 47.0 & 47.3 \\
\hline Austria & 70.4 & 66.1 \\
\hline Italy & 59.2 & 48.5 \\
\hline
\end{tabular}


Jan 1991-Dec. 1998
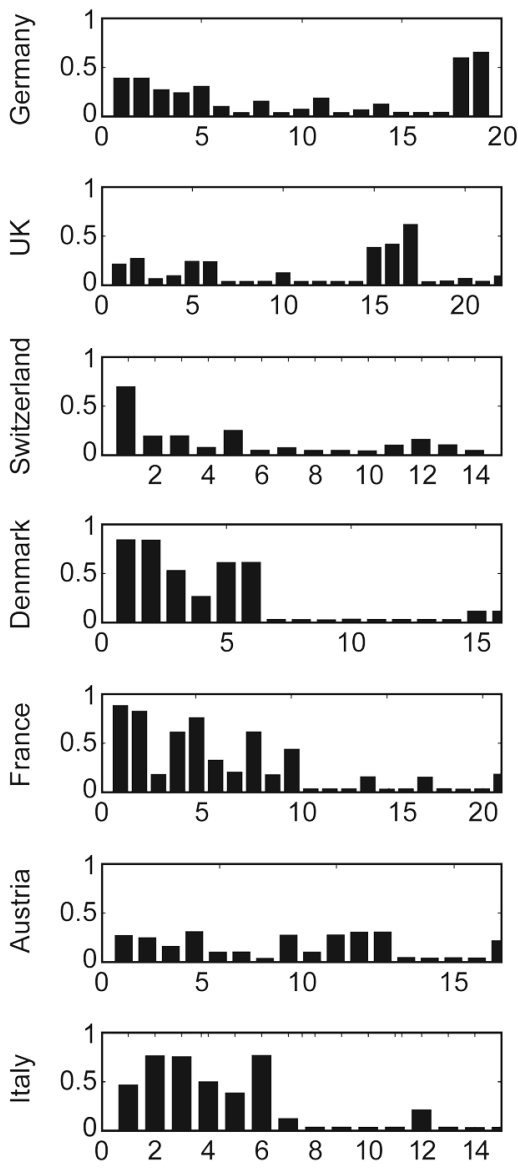

Jan 1999-Jun. 2007
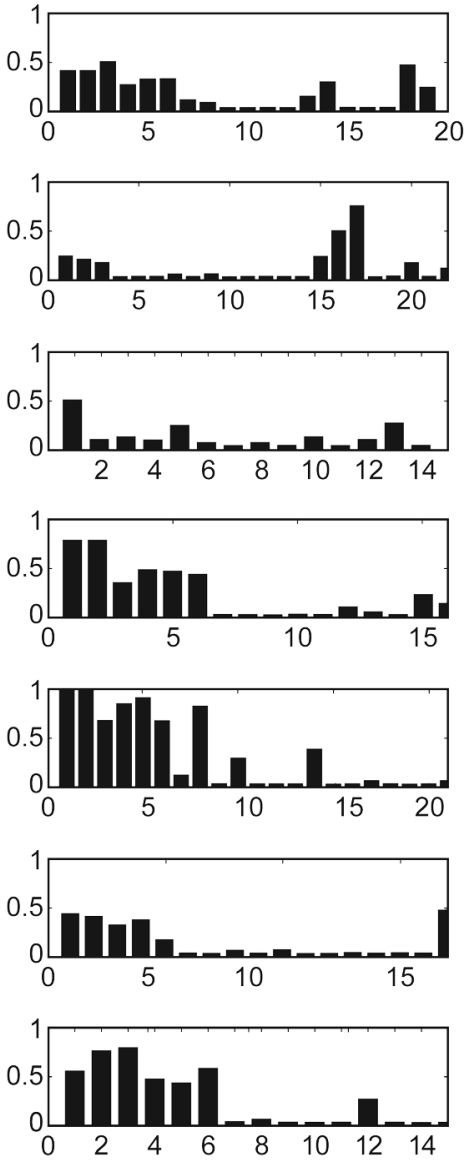

Fig. 4. $R^{2}$ of each real variable against the first factor. Since series and factors are nonstationary, they are first-differenced before applying the regression. Figures on the horizontal axis correspond to the numerical series ID given in the appendix.

crucial for most countries, although in Germany, the volume of retail trade also appears to play an important role.

If a long-run relationship exists between the estimated factors or diffusion indices and the real exchange rate, these variables should move in a common direction in the long run. In order to detect this common stochastic trend, we conducted Johansen's cointegration test using a vector autoregression involving the real exchange rate and the diffusion indices, $y=\left[q_{t}, f_{t}, f_{t}^{*}\right]$, the results of which are reported in table 3 . According to both the trace and the maximum eigenvalue statistics, we can 
Table 3

Cointegration Tests between Factors and Real Exchange Rates

\begin{tabular}{|c|c|c|c|c|c|c|}
\hline & \multicolumn{3}{|c|}{ January 1991-December 1998} & \multicolumn{3}{|c|}{ January 1999-June 2007} \\
\hline & \multirow[b]{2}{*}{ Lags } & \multicolumn{2}{|c|}{ Statistics } & \multirow[b]{2}{*}{ Lags } & \multicolumn{2}{|c|}{ Statistics } \\
\hline & & Trace & Max & & Trace & Max \\
\hline United Kingdom & 3 & $\begin{array}{c}44.01^{*} \\
(.000)\end{array}$ & $\begin{array}{c}29.06^{*} \\
(.000)\end{array}$ & 5 & $\begin{array}{c}34.32^{*} \\
(.002)\end{array}$ & $\begin{array}{c}29.43^{*} \\
(.000)\end{array}$ \\
\hline Switzerland & 2 & $\begin{array}{c}45.93^{*} \\
(.000)\end{array}$ & $\begin{array}{c}37.40^{*} \\
(.000)\end{array}$ & 8 & $\begin{array}{c}31.57^{*} \\
(.005)\end{array}$ & $\begin{array}{c}20.71^{*} \\
(.017)\end{array}$ \\
\hline Denmark & 4 & $\begin{array}{c}43.10^{*} \\
(.000)\end{array}$ & $\begin{array}{c}29.45^{*} \\
(.002)\end{array}$ & 5 & $\begin{array}{c}34.50^{*} \\
(.013)\end{array}$ & $\begin{array}{c}23.90^{*} \\
(.019)\end{array}$ \\
\hline France & 5 & $\begin{array}{c}51.02^{*} \\
(.000)\end{array}$ & $\begin{array}{c}27.12^{*} \\
(.019)\end{array}$ & 5 & $\begin{array}{c}32.74^{*} \\
(.003)\end{array}$ & $\begin{array}{c}20.36^{*} \\
(.016)\end{array}$ \\
\hline Austria & 2 & $\begin{array}{c}55.72^{*} \\
(.000)\end{array}$ & $\begin{array}{c}42.56^{*} \\
(.000)\end{array}$ & 3 & $\begin{array}{r}22.43^{*} \\
(.08)\end{array}$ & $\begin{array}{c}18.9^{*} \\
(.034)\end{array}$ \\
\hline Italy & 8 & $\begin{array}{l}9.21 \\
(.346)\end{array}$ & $\begin{array}{l}6.00 \\
(.612)\end{array}$ & 3 & $\begin{array}{c}10.72 \\
(.228)\end{array}$ & $\begin{array}{l}7.46 \\
(.435)\end{array}$ \\
\hline
\end{tabular}

Note: MacKinnon-Haug-Michelis $p$-values are in parentheses.

Significant at the $5 \%$ level for the null of no cointegration.

reject at standard significance levels the null hypothesis of no cointegration between the real exchange rate and the diffusion indices for all countries except Italy, suggesting that it would be reasonable to pursue this avenue further.

To be specific, one factor or diffusion index from each economy was included into the nonlinear system as

$$
\begin{aligned}
q_{t}= & q_{t-1}-\left(q_{t-1}-b_{1} f_{t-1}-b_{2} f_{t-1}^{*}-c\right) \\
& \times\left\{1-\exp \left[-\gamma\left(q_{t-1}-b_{1} f_{t-1}-b_{2} f_{t-1}^{*}-c\right)^{2} / \sigma_{q}^{2}\right]\right\}+e_{t},
\end{aligned}
$$

where $f_{t-1}$ and $f_{t-1}^{*}$ represent the home and foreign factors, respectively. With the inclusion of factors, we can allow for the effect of a number of macroeconomic time series on the real exchange rate in a parsimonious manner. ${ }^{18}$ Following a general-to-specific procedure, similar to that outlined in the previous subsection in which insignificant terms were sequentially excluded, we report the final results of the estimated FESTAR models, estimated by nonlinear least squares, in table 4 .

The estimation results can be summarized by the following key features. First, the $t$-statistics of the nonlinear transition parameter appear large enough to ascertain the significance of $\gamma$. When we calculated the empirical significance level as described in the previous subsection, most real exchange rates show evidence of nonlinearity except during the pre-EMU period for the United Kingdom and Switzerland and both 
EMU periods for Italy. Second, among the significant estimated transition parameters, the size increases during the EMU period for the United Kingdom, Denmark, France, and Austria. The higher estimated value of $\gamma$ in the EMU period suggests that the adjustment of real exchange rates in the presence of shocks shows faster mean reversion. In the case of Switzerland, the transition parameter is insignificant and has a smaller value in the second period. ${ }^{19}$ In the choice between ESTAR and FESTAR, the estimated factors or diffusion indices are shown to be a significant determinant of real exchange rates for the United Kingdom, Switzerland, and Austria, whereas the Danish, French, and Italian data prefer the simpler, constant-equilibrium ESTAR specification since the estimated factors are insignificant and are excluded in the model. ${ }^{20}$ The excluded factors are shown as blank cells in table 4 .

On the basis of the estimation results given in tables 1 and 4 , we plotted the estimated equilibrium level of the real exchange rate for each period and each country in figures 5 and 6 . In each figure, the equilibrium levels of the estimated parsimonious forms of the real exchange rate, driven either by the Harrod-Balassa-Samuelson effect (table 1) or by the real diffusion indices (table 4), are compared. The evidence for the existence of a time-varying real exchange rate equilibrium evident from these figures is mixed, with only about half of the countries revealing significant variation in the equilibrium. Nevertheless, given the small sample sizes involved and the difficulties previous researchers have encountered in unearthing these effects, the results are nevertheless promising.

\section{Estimated Half-Lives of Adjustment}

On the basis of the estimated models reported in tables 1 and 4, we calculated the half-lives of a range of shocks to the real exchange rates. In contrast to the linear case, estimating half-lives with nonlinear models is complicated because the ultimate effect of a shock can vary depending on the state of the system at the time of the impact of the shock as well as on the sign and magnitude of the shock. In the present analysis we follow the approach of Taylor et al. (2001) to estimate the generalized impulse response functions by Monte Carlo integration.

In particular, the impulse response function (IRF) is defined as the evolution of the effects of shocks on variables at $J$ horizons expressed as

$$
\{\operatorname{IRF}[1, s(t), h(t)], \operatorname{IRF}[2, s(t), h(t)], \ldots, \operatorname{IRF}[J, s(t), h(t)]\},
$$

where $s(t)$ is an arbitrary shock occurring at time $t$ and $h(t)$ indicates the history set of $q_{t}$. The IRF is defined as the distance between the path of $q$ 


\section{Table 4}

Estimated Nonlinear Models: FESTAR

\begin{tabular}{|c|c|c|}
\hline & 1991-98 & 1999-2007 \\
\hline \multicolumn{3}{|c|}{ United Kingdom: } \\
\hline \multirow[t]{3}{*}{$c$} & & .029 \\
\hline & -.052 & $(9.169)$ \\
\hline & $(4.873)$ & {$[.001]$} \\
\hline \multirow[t]{3}{*}{$\gamma$} & .039 & \\
\hline & $(1.314)$ & .128 \\
\hline & {$[.668]$} & $(3.632)$ \\
\hline$\beta_{1}$ & $\begin{array}{c}-.688 \\
(4.498)\end{array}$ & $\cdots$ \\
\hline \multirow[t]{3}{*}{$\beta_{2}$} & .799 & .079 \\
\hline & $(3.203)$ & $(2.692)$ \\
\hline & $z 1=[.481] ; z 2=[.009]$ & $z 1=[.837] ; z 2=[.19]$ \\
\hline \multicolumn{3}{|c|}{ Switzerland: } \\
\hline \multirow[t]{2}{*}{$c$} & -.016 & \\
\hline & $(4.218)$ & $\ldots$ \\
\hline \multirow[t]{3}{*}{$\gamma$} & .031 & .023 \\
\hline & $(1.790)$ & $(2.240)$ \\
\hline & {$[.400]$} & {$[.09]$} \\
\hline$\beta_{1}$ & $\ldots$ & $\ldots$ \\
\hline \multirow[t]{3}{*}{$\beta_{2}$} & .061 & .232 \\
\hline & $(1.851)$ & (5.435) \\
\hline & $z 1=[.846] ; z 2=[.09]$ & $z 1=[.882] ; z 2=[.833]$ \\
\hline \multicolumn{3}{|c|}{ Denmark: } \\
\hline \multirow[t]{2}{*}{$c$} & -.024 & .014 \\
\hline & $(6.780)$ & $(11.010)$ \\
\hline \multirow[t]{3}{*}{$\gamma$} & .019 & .032 \\
\hline & $(2.380)$ & $(2.670)$ \\
\hline & {$[.05]$} & {$[.024]$} \\
\hline$\beta_{1}$ & $\cdots$ & $\ldots$ \\
\hline \multirow{2}{*}{$\beta_{2}$} & $\ldots$ & $\ldots$ \\
\hline & $z 1=[.49] ; z 2=[.000]$ & $z 1=[.525] ; z 2=[.056]$ \\
\hline \multicolumn{3}{|c|}{ France: } \\
\hline \multirow[t]{2}{*}{$c$} & -.022 & .004 \\
\hline & $(6.872)$ & $(8.120)$ \\
\hline \multirow[t]{3}{*}{$\gamma$} & .018 & .080 \\
\hline & $(2.120)$ & $(3.280)$ \\
\hline & {$[.095]$} & {$[.00]$} \\
\hline$\beta_{1}$ & $\ldots$ & $\ldots$ \\
\hline \multirow[t]{2}{*}{$\beta_{2}$} & $\ldots$ & $\ldots$ \\
\hline & $z 1=[.213] ; z 2=[.064]$ & $z 1=[.608] ; z 2=[.606]$ \\
\hline
\end{tabular}


Table 4

Continued

\begin{tabular}{ccc}
\hline & $1991-98$ & $1999-2007$ \\
\hline Austria: & & \\
$c$ & -.007 & .007 \\
$\gamma$ & $(9.091)$ & $(12.060)$ \\
& .093 & .095 \\
$\beta_{1}$ & $(2.733)$ & $(3.071)$ \\
& {$[.05]$} & {$[.014]$} \\
$\beta_{2}$ & .012 & .041 \\
& $(2.397)$ & $(7.631)$ \\
Italy: & $\ldots$ & $\ldots$ \\
$c$ & $z 1=[.130] ; z 2=[.004]$ & $z 1=[.433] ; z 2=[.019]$ \\
$\gamma$ & -.074 & .015 \\
& $(4.426)$ & $(5.674)$ \\
& .013 & .017 \\
$\beta_{1}$ & $(1.756)$ & $(1.606)$ \\
$\beta_{2}$ & {$[.32]$} & {$[.538]$} \\
& $\ldots$ & $\ldots$ \\
\hline
\end{tabular}

Note: Figures in parentheses are $t$-statistics. $z 1$ is the White (1980) heteroskedasticity test statistic for serial correlation; $z 2$ is the Lagrange multiplier test for serial correlation; $z 3$ is the Lagrange multiplier test statistic for remaining nonlinearity; figures in brackets are marginal significance levels. The marginal significance levels for the estimated transition parameters were calculated by Monte Carlo simulation under the null hypothesis of a unit root $\mathrm{AR}(1)$ process.

that is expected to prevail at times $t$ through $t+J$ following an additive shock of size $s(t)$ at time $t$ and a baseline path assuming that a shock does not take place at time $t$. Formally, this can be expressed as $\operatorname{IRF}[J, s(t), h(t)]=E[q(t+n) / s(t), h(t)]-E[q(t+j) / h(t)], \quad j=1,2, \ldots, J$.

In the present analysis, 5,000 replications of the sample paths $(J=100)$, with and without a shock of size $s$ at time $t$, are simulated by randomly drawn residuals as noise for future horizons. The realizations of the differences between the two paths with and without a shock are calculated and saved. We then move up one data point and conduct this procedure again. Once the differences of the simulated paths are stored for every data point, the IRF is estimated as an average over all the simulated sequences of differences in the paths of the deviations from fundamental equilibrium with and without the shock. Therefore, the IRFs are conditional on the average history of the given $q_{t}$ series. 
Equilibrium by HBS
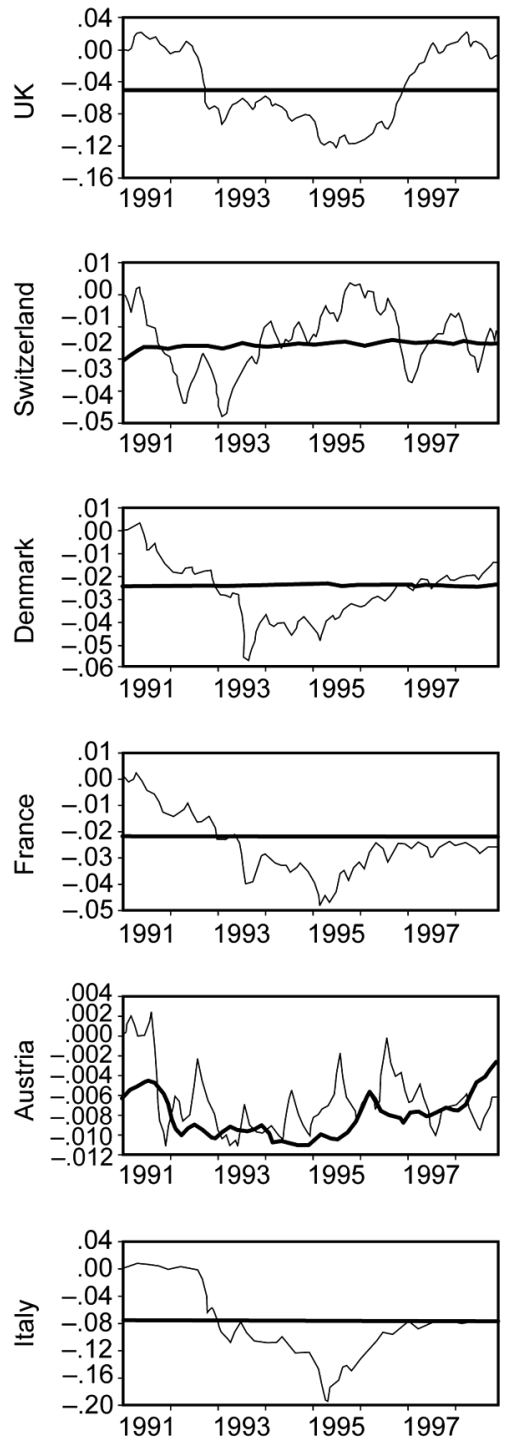

Equilibrium by Factor
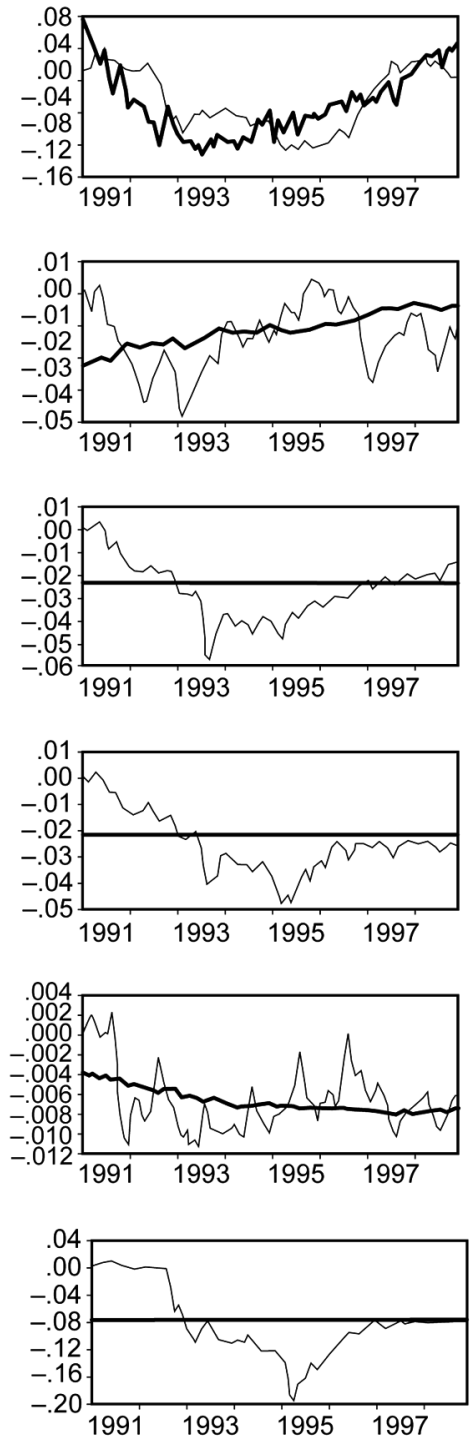

Equilibrium Level Actual Level of Real Exchange Rates

Fig. 5. Equilibrium levels of exchange rates, January 1991-December 1998. The equilibrium levels are estimated by the final parsimonious forms based on tables 1 and 4 . Actual levels of real exchange rates are normalized as zero. 
Equilibrium by HBS
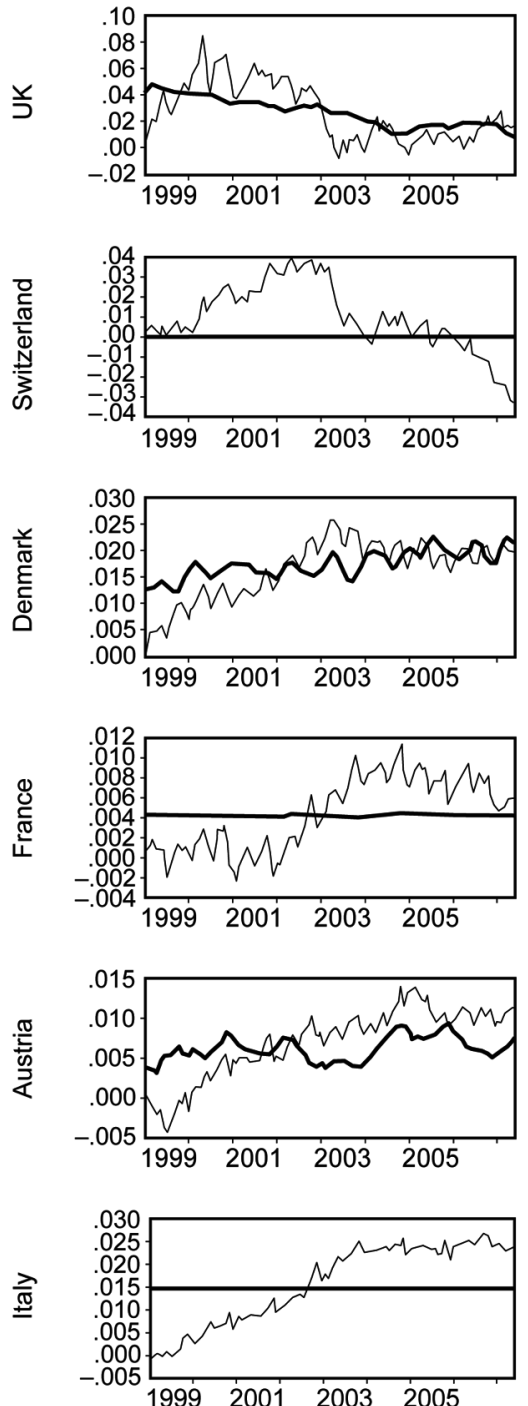

Equilibrium by Factor
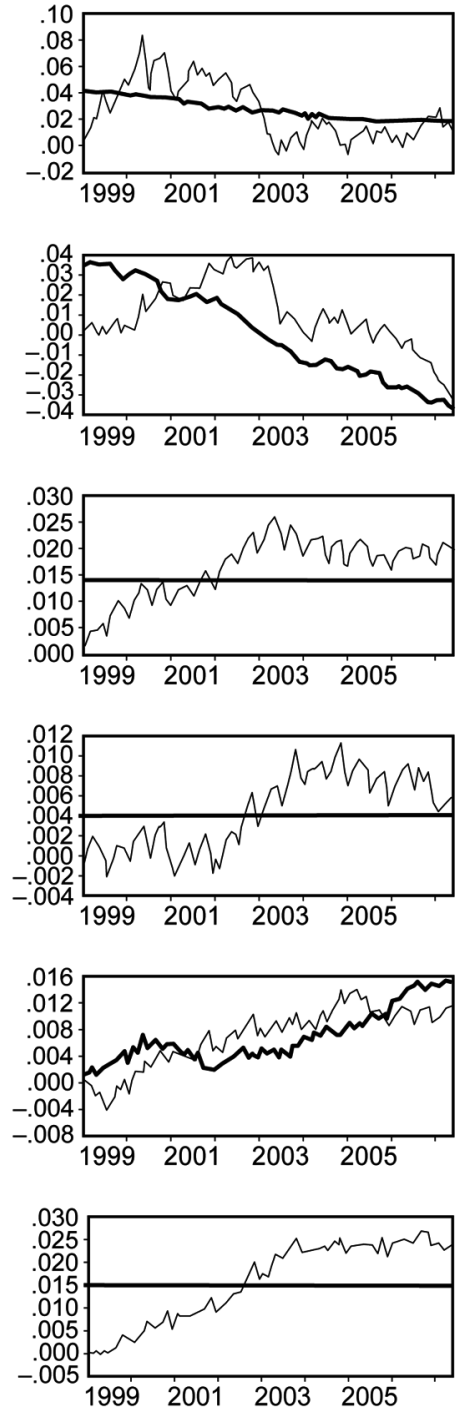

\section{Equilibrium Level}

Actual Level of Real Exchange Rates

Fig. 6. Equilibrium levels of exchange rates, January 1999-June 2007. The equilibrium levels are estimated by the final parsimonious forms based on tables 1 and 4 . Actual levels of real exchange rates are normalized as zero. 
Since the size of shock matters in a nonlinear system, five different sizes of shocks were considered, with $s$ taken from the set $\{0.5,1,5,10,20\} .{ }^{21}$ This allows us to compare how large and small shocks affect real exchange rates over time in our two different sample periods. In addition, for purposes of comparison, we also estimated simple AR(1) models and used them to estimate half-lives of adjustment under the assumption of linearity.

Table 5 summarizes the estimated IRFs. The results illustrate the nonlinear nature of the real exchange rate models, with larger shocks meanreverting much faster than smaller shocks. When the half-lives of shocks are compared between the pre-EMU and post-EMU periods, a faster speed of adjustment is found in the post-EMU case for all sizes of shocks considered and for all currencies except that of Switzerland..$^{22}$ During the period before implementation of EMU, for instance, the half-lives range from 2 to 56 months depending on the exchange rate, and the corresponding range is 2-53 months after implementation of EMU. Especially, from both panels $\mathrm{A}$ and $\mathrm{B}$ in the table, the half-lives of shocks are dramatically shortened in France after the implementation of EMU, implying that the French price indices converge more rapidly toward the German price level than that of other EMU members in the sample.

Compared to the half-lives estimated using a linear specification, our findings are consistent with the existing literature, which shows that measured half-lives of adjustment of real exchange rate shocks are shorter when measured in an explicitly nonlinear framework (Taylor et al. 2001). Overall, the results of our analysis strengthen the evidence for nonlinearities in real exchange rate adjustment and suggest that the speed of adjustment is faster for the EMU period. Faster mean reversion of real exchange rates after the implementation of EMU can be understood in the context of the rapid change of economic and monetary integration taking place in Europe.

\section{Conclusion}

A key contribution of the research reported in this paper is the incorporation of real variables into a nonlinear framework as determinants of a number of intra-European real exchange rates. We found strong evidence of nonlinearity of several European real exchange rates and some evidence of time variation in the equilibrium level of the real exchange rate. When the equilibrium real rate was modeled as a function of relative productivities, the Harrod-Balassa-Samuelson effect found some empirical support, although some of the results showed the reversed sign for the effect, which may suggest that the relative productivity gains 
Table 5

Half-Lives of Shocks (Months)

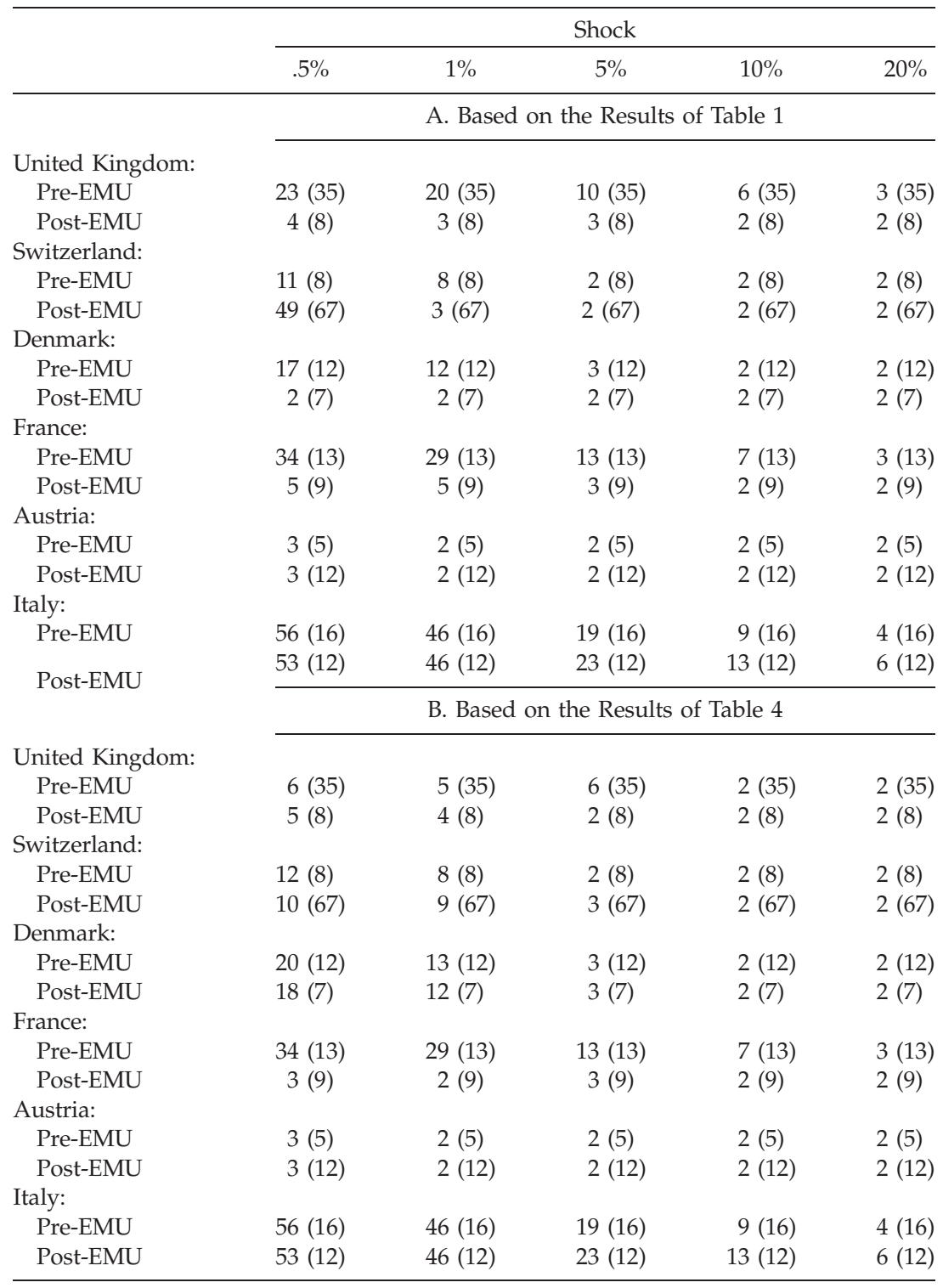

Note: The half-lives for the estimated nonlinear ESTAR and FESTAR models were calculated by Monte Carlo integration. Numbers in parentheses indicate the estimated half-lives of shocks from a simple linear AR(1) process. 
came from a "deepening" of the distributional service sector. Using real diffusion indices also allowed us to capture time variation in the real exchange rates. In both cases, a faster speed of adjustment of real exchange rates in the post-EMU period was indicated.

The evidence for the existence of time-varying real exchange rate equilibrium figures is nevertheless somewhat mixed, with only about half of the countries examined revealing significant variation in the estimated long-run equilibrium. Nevertheless, given the small sample sizes involved and the difficulties previous researchers have encountered in unearthing these effects, the results are nevertheless encouraging and suggest that further research on this issue may be warranted.

\section{Appendix}

\section{Data Used in Constructing the Diffusion Indices}

All series are obtained from DataStream with the codes given below. The bold characters with asterisks denote quarterly data interpolated to monthly frequency. The data are seasonally adjusted and put into logarithmic form as appropriate. All series are further standarized as zero mean and unit variance over the sample period in order to remove any scaling effect in the construction of the diffusion indices.

\begin{tabular}{|c|c|c|}
\hline \multicolumn{3}{|r|}{ Germany } \\
\hline ID & Code & Name \\
\hline \multicolumn{3}{|c|}{ Real output: } \\
\hline 1 & BDOPRI35H & $\begin{array}{l}\text { BD PRODUCTION OF TOTAL INDUSTRY (EXCLUDING } \\
\text { CONSTRUCTION) VOL }(2000=100)\end{array}$ \\
\hline 2 & BDOPRI38H & $\begin{array}{l}\text { BD PRODUCTION IN TOTAL MANUFACTURING VOL } \\
(2000=100)\end{array}$ \\
\hline 3 & BDOPRI61H & $\begin{array}{l}\text { BD PRODUCTION OF TOTAL MANUFACTURED } \\
\text { INTERMEDIATE GOODS VOL }(2000=100)\end{array}$ \\
\hline 4 & BDOPRI50H & $\begin{array}{l}\text { BD PRODUCTION OF MANUFACTURED DURABLE } \\
\text { CONSUMER GOODS VOL }(2000=100)\end{array}$ \\
\hline 5 & BDOPRI51H & $\begin{array}{l}\text { BD PRODUCTION OF MANUFACTURED NONDURABLE } \\
\text { CONSUMER GOODS VOL }(2000=100)\end{array}$ \\
\hline 6 & ВDIPTOT\%G & $\begin{array}{l}\text { BD INDUSTRIAL PRODUCTION INCLUDING } \\
\text { CONSTRUCTION (\%YOY) VOL }\end{array}$ \\
\hline 7 & BDOPRI08P & $\begin{array}{l}\text { BD PRODUCTION OF MANUFACTURED CRUDE } \\
\text { STEEL VOL (metric tons, thousands) }\end{array}$ \\
\hline 8 & BDPRODVTQ & $\begin{array}{l}\text { BD PRODUCTIVITY: OUTPUT PER MAN-HOUR } \\
\text { WORKED IN INDUSTRY SADJ }(2000=100)\end{array}$ \\
\hline
\end{tabular}


Continued

\begin{tabular}{|c|c|c|}
\hline \multicolumn{3}{|r|}{ Germany } \\
\hline ID & Code & Name \\
\hline \multicolumn{3}{|c|}{ Employment: } \\
\hline 9 & BDOEM047P & $\begin{array}{l}\text { BD EMPLOYMENT-PART-TIME (ECONOMIC REASON) } \\
\text { VOL }\end{array}$ \\
\hline 10 & BDOUN008P & BD REGISTERED UNEMPLOYED VOL (thousands) \\
\hline 11 & BDOUN013R & $\begin{array}{l}\text { BD REGISTERED UNEMPLMT. (\% OF CIVILIAN LABOR } \\
\text { FORCE) (\%) }\end{array}$ \\
\hline 12 & BDOUN014Q & BD STANDARDIZED UNEMPLOYMENT RATE SADJ (\%) \\
\hline \multicolumn{3}{|c|}{ 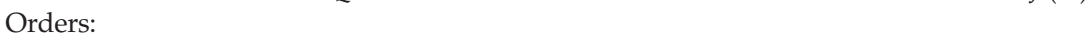 } \\
\hline 13 & BDOL0583G & $\begin{array}{l}\text { BD COMPOSITE LEADING INDICATOR: VOLUME NET } \\
\text { NEW ORDERS (MFG. VOL, } 2000=100)\end{array}$ \\
\hline 14 & BDOL0268Q & $\begin{array}{l}\text { BD COMPOSITE LEADING INDICATOR: ORDERS } \\
\text { INFLOW SADJ (\%) }\end{array}$ \\
\hline \multicolumn{3}{|c|}{$\begin{array}{l}\text { Exchange } \\
\text { rates: }\end{array}$} \\
\hline 15 & BDOCC011 & $\begin{array}{l}\text { BD REAL EFFECTIVE EXCHANGE RATE-CPI BASED } \\
\text { VON }(1995=100)\end{array}$ \\
\hline \multicolumn{3}{|c|}{ Productivity: } \\
\hline 16 & BDJAB024D & $\begin{array}{l}\text { BD PRODUCTIVITY \& LABOR COSTS: LABOR COSTS } \\
\text { PER UNIT OF OUTPUT }(2000=100)\end{array}$ \\
\hline 17 & BDJAC000D & $\begin{array}{l}\text { BD PRODUCTIVITY \& LABOR COSTS GDP DEFLATOR } \\
\text { CONA }(2000=100)\end{array}$ \\
\hline \multicolumn{3}{|c|}{ Retail trade: } \\
\hline 18 & BDOSLI15H & BD TOTAL RETAIL TRADE VOL $(2000=100)$ \\
\hline 19 & BDRETTOTG & $\begin{array}{l}\text { BD RETAIL SALES EXCL. CARS-X-12-ARIMA } \\
\quad(\text { EXPANDED SAMPLE FROM 0106) }(2000=100)\end{array}$ \\
\hline \multicolumn{3}{|r|}{ United Kingdom } \\
\hline ID & Code & Name \\
\hline
\end{tabular}

Real output:

1

2

3

4

5

6

Employment:

7

8

UKOPRI35G UK PRODUCTION OF TOTAL INDUSTRY (EXCLUDING CONSTRUCTION) VOLA $(2000=100)$

UKOPRI38G UK PRODUCTION IN TOTAL MANUFACTURING $\operatorname{VOLA}(2000=100)$

UKOPRI61G UK PRODUCTION OF TOTAL MANUFACTURED INTERMEDIATE GOODS VOLA $(2000=100)$

UKOPRI08P UK PRODUCTION OF MANUFACTURED CRUDE STEEL VOLN (metric tons, thousands)

UKOPRI13P UK PRODUCTION OF PASSENGER CARS VOLN (thousands)

UKOPRI16P UK PRODUCTION OF COMMERCIAL VEHICLES VOLN (thousands)

UKMGSW.. UK LFS: EMPLOYMENT RATE, FEMALE, AGED 16-59 \% SADJ

UKMGSS.. UK LFS: EMPLOYMENT RATE, MALE, AGED 16 \& OVER SADJ 
Continued

United Kingdom

\begin{tabular}{|c|c|c|}
\hline ID & Code & Name \\
\hline 9 & UKYBSE.. & $\begin{array}{l}\text { UK LFS: IN EMPLOYMENT, ALL, } \\
\text { AGED 16-59/64 VOLA (thousands) }\end{array}$ \\
\hline 10 & UKOUN008O & $\begin{array}{l}\text { UK REGISTERED UNEMPLOYED VOLA } \\
\text { (thousands) }\end{array}$ \\
\hline 11 & UKOUN015Q & $\begin{array}{l}\text { UK UNEMPLOYMENT RATE (\% OF TOTAL } \\
\text { LABOR FORCE) SADJ }\end{array}$ \\
\hline \multicolumn{3}{|c|}{ Consumption: } \\
\hline 12 & UKCNHLD.D* & $\begin{array}{l}\text { UK FINAL CONSUMPTION EXPENDITURE- } \\
\text { HOUSEHOLDS (CVM) CONA } \\
\text { (millions } 2003 \text { CHND PRC) }\end{array}$ \\
\hline 13 & UKCNPER.D* & $\begin{array}{l}\text { UK CONSUMER SPENDING (CVM) CONA } \\
\text { (millions, } 2000 \text { CHND PRC) }\end{array}$ \\
\hline 14 & UKI96F.CB* & $\begin{array}{l}\text { UK PRIVATE CONSUMPTION CURA } \\
\text { (pounds, millions) }\end{array}$ \\
\hline \multicolumn{3}{|r|}{ 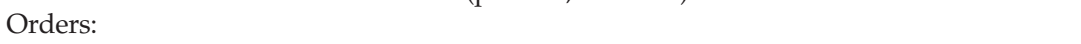 } \\
\hline 15 & UKOODI54G & $\begin{array}{l}\text { UK ORDERS FOR EXPORTED } \\
\text { MANUFACTURED GOODS (VOLUME) } \\
\text { VOLA }(2000=100)\end{array}$ \\
\hline 16 & UKOODI53G & $\begin{array}{l}\text { UK ORDERS FOR MANUFACTURED GOODS } \\
\text { FROM DOM. MARKET VOLA }(2000=100)\end{array}$ \\
\hline 17 & UKOODI45G & $\begin{array}{l}\text { UK ORDERS FOR TOTAL MANUFACTURED } \\
\text { GOODS (VOLUME) VOLA }(2000=100)\end{array}$ \\
\hline \multicolumn{3}{|c|}{ Exchange rates: } \\
\hline 18 & UKI..RECE & $\begin{array}{l}\text { UK REAL EFFECTIVE EXCHANGE RATE INDEX- } \\
\text { CPI BASED SADJ }(1995=100)\end{array}$ \\
\hline \multicolumn{3}{|r|}{ (1) } \\
\hline 19 & UKOCFRLCG & $\begin{array}{l}\text { UK LABOR COST INDEX (REAL) (AR) (DISC.) } \\
\quad \text { VOLA }(2000=100)\end{array}$ \\
\hline \multicolumn{3}{|c|}{ Retail trade: } \\
\hline 20 & UKRETTOTG & $\begin{array}{l}\text { UK RETAIL SALES: ALL RETAILERS-ALL } \\
\text { BUSINESS VOLA }(2000=100)\end{array}$ \\
\hline 21 & UKRTHOUSG & $\begin{array}{l}\text { UK RETAIL SALES: HOUSEHOLD GOODS } \\
\text { STORES-ALL BUSINESS VOLA }(2000=100)\end{array}$ \\
\hline 22 & UKRTONFDG & $\begin{array}{l}\text { UK RETAIL SALES: OTHER NONFOOD STORES- } \\
\text { ALL BUSINESS VOLA }(2000=100)\end{array}$ \\
\hline
\end{tabular}

Switzerland

\begin{tabular}{cll}
\hline ID & \multicolumn{1}{c}{ Code } & Name \\
\hline $\begin{array}{c}\text { Real output: } \\
1\end{array}$ & SWI66..IG & SW INDUSTRIAL PRODUCTION VOLA $(2000=100)$ \\
2 & SWOPRI35G* & SW PRODUCTION OF TOTAL INDUSTRY (EXCLUDING \\
& CONSTRUCTION) VOLA $(2000=100)$ \\
3 & SWOPRI38G* & SW PRODUCTION IN TOTAL MANUFACTURING \\
& & VOLA $(2000=100)$
\end{tabular}


Continued

Switzerland

\begin{tabular}{|c|c|c|}
\hline ID & Code & Name \\
\hline \multicolumn{3}{|c|}{ Employment: } \\
\hline 4 & SWOEM040H* & SW EMPLOYMENT_CIVILIAN VOLN $(2000=100)$ \\
\hline 5 & SWOEM026H* & SW CIVIL EMPL IN INDUSTRY NADJ $(2000=100)$ \\
\hline 6 & SWOEM063G* & SW CIVIL EMPL IN SERVICES VOLA $(2000=100)$ \\
\hline 7 & SWOUN015Q* & SW UNEMPLOYED \% TOTAL LABOR FORCE SADJ \\
\hline 8 & SWOPL0350* & SW TOTAL LABOR FORCE VOLA (thousands) \\
\hline 9 & SWOUN013Q* & $\begin{array}{l}\text { SW REGISTERED UNEMPLOYMENT } \\
\text { (\% OF TOTAL LABOR FORCE) SADJ }\end{array}$ \\
\hline 10 & SWUN\%TOTR* & SW UNEMPLOYMENT RATE NADJ \\
\hline \multicolumn{3}{|c|}{ Consumption: } \\
\hline 11 & SWCNPER.D* & $\begin{array}{l}\text { SW PRIVATE FINAL CONSUMPTION EXPENDITURE } \\
\text { CONA (Swiss francs, millions, } 2000 \text { CHNC PROC) }\end{array}$ \\
\hline 12 & SWCNGOV.D* & $\begin{array}{l}\text { SW GOVERNMENT FINAL CONSUMPTION } \\
\text { EXPENDITURE CONA (Swiss francs, millions, } \\
2000 \text { CHNC PROC) }\end{array}$ \\
\hline \multicolumn{3}{|r|}{ 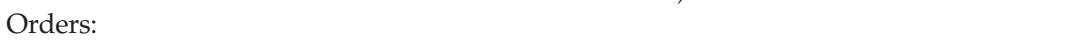 } \\
\hline 13 & SWCNORDCH $^{*}$ & $\begin{array}{l}\text { SW NEW ORDERS-CONSTRUCTION } \\
\text { (VOLUME, LAST } 3 \text { MONTHS) VOLN }\end{array}$ \\
\hline \multicolumn{3}{|c|}{ Exchange rates: } \\
\hline 14 & SWI..RECE & $\begin{array}{l}\text { SW REAL EFFECTIVE EXCHANGE RATE INDEX- } \\
\text { CPI BASED SADJ }(1995=100)\end{array}$ \\
\hline \multicolumn{3}{|r|}{ Denmark } \\
\hline ID & Code & Name \\
\hline
\end{tabular}

Real output:

1

DKOPRI35G

DK PRODUCTION OF TOTAL INDUSTRY (EXCLUDING CONSTRUCTION) VOLA $(2000=100)$

2 DKOPRI38G

DK PRODUCTION IN TOTAL MANUFACTURING $\operatorname{VOLA}(2000=100)$

$3 \quad$ DKOPRI50G

DK PRODUCTION OF MANUFACTURED DURABLE CONSUMER GOODS VOLA $(2000=100)$

4 DKOPRI51G DK PRODUCTION OF MANUFACTURED NONDURABLE CONSUMER GOODS VOLA $(2000=100)$

5 DKOPRI61G DK PRODUCTION OF TOTAL MANUFACTURED INTERMEDIATE GOODS VOLA $(2000=100)$

$6 \quad$ DKOPRI70G

Employment:

7

8

9

10

11
DKOUN013Q

DKOEM019P* DKUN\%TOTQ DKOUN014Q

DKOUN013Q
DK PRODUCTION OF TOTAL MANUFACTURED INVESTMENT GOODS VOLA $(2000=100)$

DK REGISTERED UNEMPLOYMENT (\% OF TOTAL LABOR FORCE) SADJ

DK EMPLOYEES VOLN (thousands)

DK UNEMPLOYMENT RATE SADJ (\%)

DK STANDARDIZED UNEMPLOYMENT RATE SADJ $(\%)$

DK REGISTERED UNEMPLOYMENT (\% OF TOTAL LABOR FORCE) SADJ 
Continued

Denmark

\begin{tabular}{|c|c|c|}
\hline ID & Code & Name \\
\hline \multicolumn{3}{|c|}{ Orders: } \\
\hline 12 & DKESINDMH & $\begin{array}{l}\text { DK INDL. ORDERS-MANUFACTURING, WORKING } \\
\text { ON ORDERS VOLN }(2000=100)\end{array}$ \\
\hline \multicolumn{3}{|c|}{$\begin{array}{l}\text { Exchange } \\
\text { rates: }\end{array}$} \\
\hline 13 & DKOCC011 & $\begin{array}{l}\text { DK REAL EFFECTIVE EXCHANGE RATE—CPI BASED } \\
\text { VOLN }(1995=100)\end{array}$ \\
\hline \multicolumn{3}{|r|}{ 皮 } \\
\hline 14 & DKOLC007H & $\begin{array}{l}\text { DK HOURLY EARNINGS: MANUFACTURING } \\
\text { NADJ }(2000=100)\end{array}$ \\
\hline 15 & DKRETTOTG & DK RETAIL SALES VOLA $(2000=100)$ \\
\hline 16 & DKRTOTHGG & $\begin{array}{l}\text { DK RETAIL SALES-OTHER CONSUMPTION GOODS } \\
\text { VOLA }(2000=100)\end{array}$ \\
\hline
\end{tabular}

France

\begin{tabular}{|c|c|c|}
\hline ID & Code & Name \\
\hline \multicolumn{3}{|c|}{ Real output: } \\
\hline 1 & FROPRI35H & $\begin{array}{l}\text { FR PRODUCTION OF TOTAL INDUSTRY } \\
(\text { EXCLUDING CONSTRUCTION) VOL }(2000=100)\end{array}$ \\
\hline 2 & FROPRI38H & $\begin{array}{l}\text { FR PRODUCTION IN TOTAL MANUFACTURING } \\
\quad \text { VOL }(2000=100)\end{array}$ \\
\hline 3 & FROPRI30H & $\begin{array}{l}\text { FR PRODUCTION OF TOTAL CONSTRUCTION } \\
\text { VOL }(200=100)\end{array}$ \\
\hline 4 & FROPRI49H & $\begin{array}{l}\text { FR PRODUCTION OF TOTAL MANUFACTURED } \\
\text { CONSUMER GOODS VOL }(2000=100)\end{array}$ \\
\hline 5 & FROPRI61H & $\begin{array}{l}\text { FR PRODUCTION OF TOTAL MANUFACTURED } \\
\text { INTERMEDIATE GOODS VOL }(2000=100)\end{array}$ \\
\hline 6 & FROPRI70H & $\begin{array}{l}\text { FR PRODUCTION OF TOTAL MANUFACTURED } \\
\text { INVESTMENT GOODS VOL }(2000=100)\end{array}$ \\
\hline 7 & FROPRI44H & FR PRODUCTION OF TOTAL ENERGY VOL $(2000=100)$ \\
\hline 8 & FROPRI47H & $\begin{array}{l}\text { FR PRODUCTION IN TOTAL AGRICULTURE } \\
\text { VOL }(2000=100)\end{array}$ \\
\hline 9 & FROPRI08P & $\begin{array}{l}\text { FR PRODUCTION OF MANUFACTURED CRUDE STEEL } \\
\text { VOL (meteoric thousands) }\end{array}$ \\
\hline 10 & FROPRI58H & FR PRODUCTION OF TOTAL VEHICLES VOL \\
\hline \multicolumn{3}{|c|}{ Employment: } \\
\hline 11 & FROEM006O & FR EMPLOYMENT INDUSTRY (OLD) VOLA (thousands) \\
\hline 12 & FROEM012O & $\begin{array}{l}\text { FR EMPLOYMENT-MARKET SERVICES VOLA } \\
\text { (thousands) }\end{array}$ \\
\hline 13 & FROUN008P & FR REGISTERED UNEMPLOYED VOL (thousands) \\
\hline 14 & FROUN007G & $\begin{array}{l}\text { FR NEW UNEMPLOYMENT CLAIMS SADJ } \\
\text { (actual thousands) }\end{array}$ \\
\hline 15 & FROUN014Q & $\begin{array}{l}\text { FR STANDARDIZED UNEMPLOYMENT RATE } \\
\text { SADJ }(2000=100)\end{array}$ \\
\hline 16 & FROUN015Q & $\begin{array}{l}\text { FR UNEMPLOYMENT RATE (\% OF TOTAL LABOR } \\
\text { FORCE) SADJ }\end{array}$ \\
\hline
\end{tabular}


Continued

\begin{tabular}{|c|c|c|}
\hline \multicolumn{3}{|r|}{ France } \\
\hline ID & Code & Name \\
\hline \multicolumn{3}{|c|}{ Housing started: } \\
\hline 17 & FRHOUSE.P & FR HOUSING STARTED VOL (actual) \\
\hline \multicolumn{3}{|c|}{ Consumption: } \\
\hline 18 & FRCNHLD.D & $\begin{array}{l}\text { FR HOUSEHOLD CONSUMPTION CONA } \\
\text { (euros, millions) }\end{array}$ \\
\hline 19 & FRCNPER.D & FR CONSUMER SPENDING CONA (euros, millions) \\
\hline \multicolumn{3}{|c|}{ Exchange rates: } \\
\hline 20 & FRI..RECE & $\begin{array}{l}\text { FR REAL EFFECTIVE EXCHANGE RATE INDEX- } \\
\text { CPI BASED SADJ }(1995=100)\end{array}$ \\
\hline \multicolumn{3}{|c|}{ Retail trade: } \\
\hline 21 & FROSLI15H & $\begin{array}{l}\text { FR TOTAL RETAIL TRADE (VOLUME) VOLN } \\
\quad(2000=100)\end{array}$ \\
\hline
\end{tabular}

\begin{tabular}{|c|c|c|}
\hline \multicolumn{3}{|r|}{ Austria } \\
\hline ID & Code & Name \\
\hline \multicolumn{3}{|c|}{ Real output: } \\
\hline 1 & OEOPRI35H & $\begin{array}{l}\text { OE PRODUCTION OF TOTAL INDUSTRY } \\
(\text { EXCLUDING CONSTRUCTION) VOL }(2000=100)\end{array}$ \\
\hline 2 & OEOPRI38H & $\begin{array}{l}\text { OE PRODUCTION IN TOTAL MANUFACTURING } \\
\text { VOL }(2000=100)\end{array}$ \\
\hline 3 & OEOPRI61H & $\begin{array}{l}\text { OE PRODUCTION OF TOTAL MANUFACTURED } \\
\text { INTERMEDIATE GOODS VOL }(2000=100)\end{array}$ \\
\hline 4 & OEOPRI70H & $\begin{array}{l}\text { OE PRODUCTION OF TOTAL MANUFACTURED } \\
\text { INVESTMENT GOODS VOL }(2000=100)\end{array}$ \\
\hline 5 & OEOPRI08P & $\begin{array}{l}\text { OE PRODUCTION OF MANUFACTURED CRUDE } \\
\text { STEEL VOL (meteoric thousands) }\end{array}$ \\
\hline \multicolumn{3}{|c|}{ Employment: } \\
\hline 6 & OEOEM019O & OE DEPENDENT EMPLOYMENT VOLA (thousands) \\
\hline 7 & OEOEM011O & OE EMPLOYMENT—SERVICES VOLA (thousands) \\
\hline 8 & OEOUN008P & OE REGISTERED UNEMPLOYED VOLN (thousands) \\
\hline 9 & OEVACTOTP & OE JOB VACANCIES VOLN (actual) \\
\hline 10 & OEUNPTOTP & OE UNEMPLOYED—REGISTERED VOLN (actual) \\
\hline 11 & OEUN\%TOTR & OE UNEMPLOYMENT RATE \% NADJ \\
\hline 12 & OEOUN012R & $\begin{array}{l}\text { OE UNEMPLOYMENT (\% OF CIVIL LABOR } \\
\text { FORCE) NADJ }\end{array}$ \\
\hline \multicolumn{3}{|c|}{ Consumption: } \\
\hline 13 & OECNPER.D* & $\begin{array}{l}\text { OE PRIVATE CONSUMPTION EXPENDITURE } \\
\text { CONA ( } 2000 \text { CHNC PROC) }\end{array}$ \\
\hline \multicolumn{3}{|c|}{ Exchange rates: } \\
\hline 14 & OEI..RECE & $\begin{array}{l}\text { OE REAL EFFECTIVE EXCHANGE RATE } \\
\text { INDEX-CPI BASED SADJ }(1995=100)\end{array}$ \\
\hline
\end{tabular}


Continued

\begin{tabular}{|c|c|c|}
\hline \multicolumn{3}{|r|}{ Austria } \\
\hline ID & Code & Name \\
\hline \multicolumn{3}{|c|}{ Earnings: } \\
\hline 15 & OEOLC007H & $\begin{array}{l}\text { OE COMPOSITE LEADING INDICATOR: MONTHLY } \\
\text { EARN-MINING \& MANUFACTURING NADJ } \\
(2000=100)\end{array}$ \\
\hline 16 & OEOLC006H $^{*}$ & $\begin{array}{l}\text { OE MONTHLY EARNINGS: MINING \& } \\
\text { MANUFACTURING NADJ }(2000=100)\end{array}$ \\
\hline \multicolumn{3}{|c|}{ Retail trade: } \\
\hline 17 & OEOSLI15H & $\begin{array}{l}\text { OE TOTAL RETAIL TRADE (VOLUME) } \\
\text { VOLN }(2000=100)\end{array}$ \\
\hline
\end{tabular}

\begin{tabular}{|c|c|c|}
\hline \multicolumn{3}{|r|}{ Italy } \\
\hline ID & Code & Name \\
\hline \multicolumn{3}{|c|}{ Real output: } \\
\hline 1 & ITIPTOT.G & IT INDUSTRIAL PRODUCTION VOLA (2000 = 100) \\
\hline 2 & ITOPRI35H & $\begin{array}{l}\text { IT PRODUCTION OF TOTAL INDUSTRY } \\
(\text { EXCLUDING CONSTRUCTION) VOLN }(2000=100)\end{array}$ \\
\hline 3 & ITOPRI38H & $\begin{array}{l}\text { IT PRODUCTION IN TOTAL MANUFACTURING } \\
\text { VOLN }(2000=100)\end{array}$ \\
\hline 4 & ITOPRI49G & $\begin{array}{l}\text { IT PRODUCTION OF TOTAL MANUFACTURED } \\
\text { CONSUMER GOODS VOLA }(2000=100)\end{array}$ \\
\hline 5 & ITOPRI61G & $\begin{array}{l}\text { IT PRODUCTION OF TOTAL MANUFACTURED } \\
\text { INTERMEDIATE GOODS VOLA }(2000=100)\end{array}$ \\
\hline 6 & ITOPRI61H & $\begin{array}{l}\text { IT PRODUCTION OF TOTAL MANUFACTURED } \\
\text { INTERMEDIATE GOODS VOLN }(2000=100)\end{array}$ \\
\hline 7 & ITOPRI08P & $\begin{array}{l}\text { IT PRODUCTION OF MANUFACTURED CRUDE } \\
\text { STEEL VOLN }(2000=100)\end{array}$ \\
\hline \multicolumn{3}{|c|}{ Employment: } \\
\hline 8 & ITOUN014Q & IT STANDARDIZED UNEMPLOYMENT RATE SADJ \\
\hline 9 & ITOUN010P* & IT UNEMPLOYMENT VOLN (thousands) \\
\hline 10 & ITOUN015R* & $\begin{array}{l}\text { IT UNEMPLOYMENT RATE (\% OF TOTAL } \\
\text { LABOR FORCE) NADJ }\end{array}$ \\
\hline 11 & ITOEM040H* & IT EMPLOYMENT—CIVILIAN VOLN \\
\hline \multicolumn{3}{|c|}{ Orders: } \\
\hline 12 & ITOL0583G & $\begin{array}{l}\text { IT COMPOSITE LEADING INDICATOR: VOLUME } \\
\text { NET NEW ORDERS (MFG.) VOLA }(2000=100)\end{array}$ \\
\hline \multicolumn{3}{|r|}{ (2) } \\
\hline 13 & ITI..RECE & $\begin{array}{l}\text { IT REAL EFFECTIVE EXCHANGE RATE INDEX- } \\
\text { CPI BASED SADJ }(1995=100)\end{array}$ \\
\hline \multicolumn{3}{|c|}{ Earnings: } \\
\hline 14 & ITOCFRLCG* & $\begin{array}{l}\text { IT LABOR COST INDEX (REAL) (AR) (DISC.) } \\
\text { VOLA }(2000=100)\end{array}$ \\
\hline \multicolumn{3}{|c|}{ Retail trade: } \\
\hline 15 & ITSLI15G & $\begin{array}{l}\text { IT TOTAL RETAIL TRADE (VOLUME) } \\
\text { VOLA }(2000=100)\end{array}$ \\
\hline
\end{tabular}




\section{Endnotes}

1. Their study suggests that differing speeds of adjustment at a disaggregated good level can be translated into an "aggregation bias" in measures of real exchange rate adjustment that employ linear econometric techniques. When heterogeneity in adjustment is allowed for, Imbs et al. argue that their empirical findings point to an average speed of mean reversion much faster than what Rogoff (1996) refers to as the "glacial" speed of adjustment of 3-5 years reported in the literature. For criticism of this argument, however, see Chen and Engel (2005). See also Engel (2000).

2. For simplicity, we ignore the constant of integration.

3. In particular, Devereux (1999) explains the lack of strong real appreciation in Hong Kong and Singapore dollars as attributable to fast productivity growth in the service sector. Supporting empirical evidence is also presented by Muscatelli, Spinelli, and Trescroci (2007).

4. For simplicity, we take the wholesale price of tradables as numeraire $\left(P_{W}=1\right)$.

5. This is more likely with smaller $\rho$ (i.e., a greater specialization effect).

6. While factors estimated by maximum likelihood may be better specified when $N$ is small, the principal components method is more practicable when $N$ is large.

7. As briefly discussed above, an alternative nonlinear model, the threshold autoregressive model, allows for a transactions costs band within which no adjustment take place. But many of the theoretical studies suggest that, for aggregate real exchange rates, smooth rather than discrete adjustment may be more appropriate in the presence of proportional transaction costs, time aggregation, and nonsynchronous adjustment by heterogeneous agents (Taylor 2003).

8. Examination of the partial autocorrelation functions indicated that a first-order autoregressive model would be adequate in every case for our data, and a first delay parameter was also chosen on the basis of a set of nested likelihood ratio tests. We therefore discuss only the first-order model in order to simplify the exposition.

9. If series were available only on a quarterly basis, they were interpolated to the monthly frequency. In the case of Switzerland, the majority of data sets are converted to monthly series. More details on the data sets are given in the appendix.

10. Ideally, one would like to obtain data on tradable sector output and employment, but data on capital inputs are notoriously unreliable as Froot and Rogoff (1995) indicate; hence we use aggregate productivity.

11. To better observe the comovement between the series, we adjust the mean and variances of the individual series if necessary.

12. A rise in an economy's unit labor costs represents an increased reward for labor's contribution to output. Hence, a rise in labor costs over and above the rise in labor productivity may be a threat to an economy's international cost competitiveness.

13. Hence, some of the estimated results are in the form of a simple ESTAR model with a constant equilibrium.

14. Analogous to the way in which the distribution of the Dickey-Fuller statistic cannot be assumed to be distributed as Student's $t$ or normal.

15. Note that the particular parameterization of eq. (30) implies that the real exchange rate is independent of the time-varying equilibrium when $\gamma=0$.

16. The method of estimation of the empirical significance levels follows the procedure described in Taylor et al. (2001), with 5,000 simulations. Since the parameterization (30) implies that the real exchange rate is independent of the time-varying equilibrium when $\gamma=0$, the simulated real exchange rate data can be generated independently under the null hypothesis.

17. For Austria, the empirical significance level lies on the $10 \%$ borderline of the rejection region.

18. Kim and Taylor (2008) calculate the speed of adjustment of real exchange rates for U.S. dollar-sterling, U.S. dollar-yen, and U.S. dollar-Australian dollar during the postBretton Woods period. They find that ignoring the influences of large data sets in a standard univariate evaluation of a nonlinear specification leads to biased results in measuring real exchange rate adjustment. 
19. In fig. 1, the Swiss real exchange rate shows an unusual degree of volatility given the observation period, which looks notably different from the other real exchange rates.

20. A nonlinearity test in Italy is insignificant for both periods, suggesting that a nonlinear framework is not suitable to model the Italian real exchange rate for the given sample period.

21. A shock of $s \%$ to the level of the real exchange rate is equivalent to adding $\log (1+s / 100)$ to $q_{t}$; the half-life is the time taken for the IRF to fall below $0.5 \log (1+s / 100)$. The half-lives calculated for the models with a significant time-varying equilibrium are conditional on the observed path of that equilibrium over the sample period.

22. The result from a linear AR(1) process has a similar result for Switzerland; the halflives of shocks are more persistent in the post-EMU period.

\section{References}

Bai, J. 2003. “Inferential Theory for Factor Models of Large Dimensions." Econometrica 71, no. 1:135-71.

Balassa, B. 1964. "The Purchasing Power Parity Doctrine: A Reappraisal." Journal of Political Economy 72:584-96.

Bergin, P. R., R. Glick, and A. M. Taylor. 2006. "The Productivity, Tradability and the Long-Run Price Puzzle." Journal of Monetary Economics 53:2041-66.

Bernanke, B., and J. Boivin. 2003. "Monetary Policy in a Data-Rich Environment." Journal of Monetary Economics 50 (April): 525-46.

Bernanke, B., J. Boivin, and P. Eliasz. 2005. "Measuring the Effects of Monetary Policy: A Factor-Augmented Vector Autoregressive (FAVAR) Approach." Quarterly Journal of Economics 120:387-422.

$\rightarrow$ Chen, S.-S., and C. Engel. 2005. "Does 'Aggregation Bias' Explain the PPP Puzzle?" Pacific Economic Review 10, no. 1:49-72.

$\rightarrow$ Cheung, Y. W., M. Chinn, and E. Fujii. 2001. "Market Structure and the Persistence of Sectoral Real Exchange Rates." International Journal of Finance and Economics 6, no. 2:95-114.

$\rightarrow$ Devereux, M. B. 1999. "Real Exchange Rate Trends and Growth: A Model of East Asia." Review of International Economics 7:509-21.

$\rightarrow$ Dumas, B. 1992. "Dynamic Equilibrium and the Real Exchange Rate in a Spatially Separated World." Review of Financial Studies 5:153-80.

$\rightarrow$ Engel, C. 2000. "Long-Run PPP May Not Hold after All." Journal of International Economics 51:243-73.

$\rightarrow$ Fratzscher, M. 2008. "Oral Interventions versus Actual Interventions in Fx Markets-an Event-Study Approach." Economic Journal 118:1079-1106.

$\rightarrow$ Froot, K. A., and K. Rogoff. 1991. "The EMS, the EMU, and the Transition to a Common Currency." Macroeconomics Annual 1991:269-317.

—_. 1995. "Perspectives on PPP and Long-Run Real Exchange Rates." In Handbook of International Economics, ed. G. Grossman and K. Rogoff, 1647-88. Amsterdam: North-Holland.

Granger, C., and T. Teräsvirta. 1993. Modelling Nonlinear Economic Relationships. Oxford: Oxford University Press.

Harrod, R. 1933. International Economics. London: Nisbet and Cambridge University Press.

$\rightarrow$ Imbs, J., H. Mumtaz, M. O. Ravn, and H. Rey. 2005. “PPP Strikes Back: Aggregation and the Real Exchange Rate." Quarterly Journal of Economics 120:1-43.

$\rightarrow$ Kilian, L., and M. P. Taylor. 2003. "Why Is It So Difficult to Beat the Random Walk Forecast of Exchange Rates?" Journal of International Economics 60:85-117.

Kim, H., and M. P. Taylor. 2008. "Large Data Sets, Nonlinearity and the Speed of Adjustment of Real Exchange Rates." Manuscript, Department of Economics, University of Warwick. 
Lothian, J. R., and M. P. Taylor. 2008. "Real Exchange Rates over the Past Two Centuries: How Important Is the Harrod-Balassa-Samuelson Effect?" Economic Journal 118:1742-63.

$\rightarrow$ Michael, P. A., R. Nobay, and D. Peel. 1997. "Transactions Costs and Nonlinear Adjustment in Real Exchange Rates: An Empirical Investigation." Journal of Political Economy 105:862-79.

$\rightarrow$ Muscatelli, V. A., F. Spinelli, and C. Trescroci. 2007. "Macroeconomic Shocks, Structural Change and Real Exchange Rates: Evidence from Historical Data." Journal of International Money and Finance 26:1403-23.

$\rightarrow$ Obstfeld, M., and A. M. Taylor. 1997. "Nonlinear Aspects of Goods-Market Arbitrage and Adjustment: Heckscher's Commodity Points Revisited." Journal of the Japanese and International Economies 11 (December): 441-79.

$\rightarrow$ O'Connell, P. G. 1997. "The Overvaluation of Purchasing Power Parity." Journal of International Economics 44:1-19.

$\rightarrow$ Reitz, S., and M. P. Taylor. 2009. "The Coordination Channel of Foreign Exchange Intervention: A Nonlinear Microstructural Analysis." European Economic Review 52:55-76.

$\rightarrow$ Rogoff, K. 1996. "The Purchasing Power Parity Puzzle." Journal of Economic Literature 34:647-68.

$\rightarrow$ Samuelson, P. A. 1964. "Theoretical Notes on Trade Problems." Review of Economics and Statistics 46:145-54.

$\rightarrow$ Sarno, L., M. P. Taylor, and I. Chowdhury. 2002. "Nonlinear Dynamics in the Law of One Price: A Broad-Based Empirical Study." Journal of International Money and Finance 23:1-25.

$\rightarrow$ Sercu, P., R. Uppal, and C. Van Hulle. 1995. "The Exchange Rate in the Presence of Transactions Costs: Implication for Tests of Purchasing Power Parity." Journal of Finance 50:1309-19.

Stock, J., and M. Watson. 1998. "Diffusion Indexes." Working Paper no. 6702, NBER, Cambridge, MA.

$\rightarrow$. 2002a. "Forecasting Using Principal Components from a Large Number of Predictors." Journal of the American Statistical Association 97:1167-79.

$\rightarrow-$. 2002b. "Macroeconomic Forecasting Using Diffusion Indexes." Journal of Business and Economic Statistics 20:147-62.

$\rightarrow$ Taylor, A. M., and M. P. Taylor. 2004. "The Purchasing Power Parity Debate." Journal of Economic Perspectives 14:135-58.

Taylor, M. P. 2003. "Purchasing Power Parity." Review of International Economics 11:436-52.

$\rightarrow$ — 2004. "Is Official Exchange Rate Intervention Effective?" Economica 71:1-11.

$\rightarrow$ Taylor, M. P., and D. A. Peel. 2000. “Nonlinear Adjustment, Long-Run Equilibrium and Exchange Rate Fundamentals." Journal of International Money and Finance 19:33-53.

$\rightarrow$ Taylor, M. P., D. A. Peel, and L. Sarno. 2001. "Nonlinear Mean-Reversion in Real Exchange Rates: Toward a Solution to the Purchasing Power Parity Puzzles." International Economic Review 42:1015-42.

$\rightarrow$ Teräsvirta, T. 1994. "Specification, Estimation and Evaluation of Smooth Transition Autoregressive Models." Journal of the American Statistical Association 89:208-18.

$\rightarrow$ White, H. 1980. "A Heteroskedasticity-Consistent Covariance Matrix Estimator and a Direct Test for Heteroskedasticity." Econometrica 48 (May): 817-38. 